\title{
Ongerechtvaardigde verrijking naar Nederlands recht
}

Ton Hartlief*

\section{Inleiding en plan van behandeling}

\section{BW 1992 is niet het $\mathrm{BW}{ }_{1} 838$}

Een bespreking van het Nederlandse recht wordt gedomineerd door het feit dat het huidige BW in art. 6:212 een algemene verrijkingsactie kent, waarvoor de Hoge Raad binnen het oude recht geen ruimte zag: ${ }^{809}$

I. Hij die ongerechtvaardigd is verrijkt ten koste van een ander, is verplicht, voor zover dit redelijk is, diens schade te vergoeden tot het bedrag van zijn verrijking.

2. Voor zover de verrijking is verminderd als gevolg van een omstandigheid die niet aan de verrijkte kan worden toegerekend, blijft zij buiten beschouwing.

3. Is de verrijking verminderd in de periode waarin de verrijkte redelijkerwijze met een verplichting tot vergoeding van de schade geen rekening behoefde te houden, dan wordt hem dit niet toegerekend. Bij de vaststelling van deze vermindering wordt mede rekening gehouden met uitgaven die zonder de verrijking zouden zijn uitgebleven.

Met de erkenning van een algemene verrijkingsactie wijkt het huidige BW dus af van zijn voorganger, maar vaart het eenzelfde koers als enkele andere zogenoemde 'moderne' wetboeken. Dat betekent niet dat de (praktische) betekenis van deze actie overal dezelfde is. Zo kennen sommige stelsels een in meer of mindere mate achtergestelde positie van de verrijkingsactie bijvoorbeeld doordat zij het subsidiariteitsvereiste stellen. Het Nederlandse recht, zo komt nog aan de orde, ${ }^{810}$ gaat daarvan echter niet uit. De verrijkingsactie lijkt zo een gewone actie die net als de vordering uit contract of onrechtmatige daad een volwaardige positie inneemt. Daarbij past dat de Hoge Raad in zijn rechtspraak sinds 1992 herhaaldelijk toepassing heeft gegeven

* Hoogleraar privaatrecht aan de Universiteit Maastricht. Met dank aan Gerrit van Maanen en Lotte Meurkens voor opmerkingen en suggesties naar aanleiding van een eerdere versie.

809 HR 30 januari 1959, NJ 1959, 548 (DJV) (Quint/Te Poel).

8Io Hierna nr. 25. 
aan art. 6:2I2. Het meest gezaghebbend handboek stelt dat de algemene verrijkingsactie daarin $:{ }^{81}$

'op onbekrompen wijze wordt aanvaard'.

Ook Vranken valt op: ${ }^{812}$

'hoe ongedwongen, laconiek bijna, de Hoge Raad sedert 1992 met het onderwerp omspringt.'

2. Omstreden rechtspraak Deze beelden en het enthousiasme dat daaruit spreekt, worden echter niet door iedereen gedeeld. Diverse geleerden hebben hun pijlen gericht op de verrijkingsrechtspraak van de Hoge Raad. Zo trekt Nieskens-Isphording in 1998 een stevige conclusie: ${ }^{813}$

'Gekozen lijkt te worden voor een 'billijkheidsactie' die het mogelijk maakt op (gevoelsmatig) redelijke gronden tot juridisch niet toetsbare resultaten te komen.'

Zwalve is in 1997 zo mogelijk nog harder in zijn oordeel: ${ }^{814}$

'de Hoge Raad wil de vordering uit ongerechtvaardigde verrijking zo veel mogelijk ruimte geven. Zij is lang een troetelkind van de rechtsgeleerdheid geweest, niet alleen in Nederland, maar ook elders en heeft nu, zij het na enige (gerechtvaardigde) aarzeling, haar plaats gevonden in het nieuwe BW. Dan moet er ook iets mee gedaan worden, zo moet de Hoge Raad hebben gedacht. Hij heeft een nieuw speeltje en doet daar leuke dingen mee voor de mensen.'

En ook Van Maanen, we schrijven 200I, is niet mals in zijn kritiek in zijn Ars Aequi Cahier over Ongerechtvaardigde verrijking dat niet voor niets een ondertitel heeft (Een handleiding voor raadsheren en studenten, met gratis stappenplan) en besluit met een aan duidelijkheid niets te wensen overlatend verlangen: ${ }^{815}$

'het hek moet weer op de dam...'

3. Agenda Literatuur en rechtspraak, zo lijkt het beeld, zitten niet direct op één lijn. Vooral rond de millenniumwisseling houdt het leerstuk van de ongerechtvaardigde verrijking de gemoederen bezig. Object van bespreking vormt daarbij steevast de rechtspraak van de Hoge Raad. Wat daarvan zij, de Hoge Raad heeft, al dan niet

8II Asser-Hartkamp/Sieburgh 6-IV, Verbintenissenrecht. De verbintenis uit de wet, Ize druk, Kluwer, Deventer 20II, nr. 359.

8I2 J.B.M. Vranken, 'De strijd om het verrijkingsrecht', NJB I998, p. I495.

8I3 B.W.M. Nieskens-Isphording, 'Een analyse van zes jaar ongerechtvaardigde verrijking', RMThemis 1998 , p. Iog.

8I4 W.J. Zwalve, 'Dubbele Verkoop en Ongerechtvaardigde Verrijking', WPNR 6282 (I997), p. 586.

8I5 G.E. van Maanen, Ongerechtvaardigde verrijking, Ars Aequi Cahier, Ars Aequi, Nijmegen 200I, p. 5 I. 
terecht, gebruik gemaakt van de ruimte die het huidige BW geeft. Die ruimte wordt niet alleen bepaald door het feit van een algemene verrijkingsactie als zodanig, maar ook door het gegeven dat aan de toepassing daarvan geen bijzondere voorwaarden zijn verbonden. Ik laat het nu bij de constatering dat het Nederlandse recht ten eerste geen subsidiariteitsvereiste kent, zodat het gegeven dat de verarmde een andere vordering heeft op de verrijkte of een derde niet aan een vordering op grond van art. 6:212 in de weg staat en zich ten tweede ook uitstrekt tot zogenoemde gevallen van indirecte of derdenverrijking waarbij de verrijking is terechtgekomen in het vermogen van een derde. Neem het geval van een aannemer die onder eigendomsvoorbehoud goederen geleverd krijgt, die vervolgens door hem worden verwerkt bij de bouw van een pand ten behoeve van een derde. Deze wordt door natrekking eigenaar. Wanneer de aannemer niet in staat is zijn leverancier te betalen, komt een verrijkingsvordering van de leverancier op de eigenaar van het pand in beeld. Op zich verzet niets zich tegen toepassing van art. 6:2I2 op dergelijke gevallen van indirecte verrijking. Het ontbreken van dergelijke beperkingen 'op voorhand' maakt het potentiële toepassingsbereik van art. 6:2I2 zeer groot. Deze achtergrond, die, zoals duidelijk uit de bijdrage van mijn mede-preadviseur Joke Baeck blijkt, sterk verschilt van die van het Belgische recht, bepaalt mijn agenda. In dit preadvies zal ik art. 6:212 en het debat over de in dit kader ontwikkelde rechtspraak doorlichten, uiteraard om te bepalen waar we op dit moment staan, maar ook om daarmee de Belgische lezer voor te lichten en hem in staat te stellen de Nederlandse ervaringen mee te nemen bij het beantwoorden van de vraag wat naar Belgisch recht wenselijk is. Ongetwijfeld komt ook voor het Nederlandse recht aan bod waar het heen zou kunnen gaan. Onze preadviezen hebben door deze verschillen in uitgangspunt ook een uiteenlopende focus: waar in het Belgische preadvies eerder het perspectief is dat meer duidelijkheid over de toepassingsvoorwaarden zal kunnen leiden tot ruimere toepassingsmogelijkheden, is de invalshoek in het Nederlandse preadvies veel meer dat het ruime toepassingsbereik van de verrijkingsactie en de wijze waarop de Hoge Raad haar tegemoet treedt, zorgen baren althans aanleiding geven tot een nadere plaatsbepaling.

4. Lijn van het betoog Dit preadvies waarin het Nederlandse recht centraal staat, kent de volgende opbouw. ${ }^{816}$ Allereerst volgt in paragraaf 2 een korte aanloop en bespreking van de voorgeschiedenis die loopt van het arrest Quint/Te Poel naar art. 6:212. Diens parlementaire lotgevallen staan uiteraard centraal. Vervolgens wordt art. 6:2I2 in paragraaf 3 nader bekeken, komen de voorwaarden die aan een succesvolle actie worden gesteld aan bod en wordt ook de omvang van de vergoeding als zodanig besproken. Bovendien komt in dit verband ook de vraag naar eventuele subsidiariteit aan de orde. In paragraaf 4 wordt de verrijkingsactie in het wettelijk systeem 'gesitueerd', omdat voor de praktische betekenis van art. 6:2I2 uiteraard

8I6 In het preadvies van Joke Baeck waarin voor het Belgische recht wordt gezocht naar duidelijkheid over de toepassingsvoorwaarden mede met het oog op (ruimere) toepassingsmogelijkheden voor de verrijkingsactie, wordt niet zonder reden ook meer aandacht besteed aan het DCFR dat Boek VII heeft gewijd aan ongerechtvaardigde verrijking. 
relevant is welke (bronnen van) verbintenissen het systeem verder nog kent. Daarbij wordt het potentieel zeer ruime toepassingsbereik in beeld gebracht en komt aan de orde wat de verrijkingsactie ten onzent tot een omstreden rechtsfiguur maakt. Paragraaf 5 is misschien wel de kern van het preadvies omdat daarin de 'hausse' aan aandacht in de doctrine voor het leerstuk en zijn toepassing in de rechtspraak van de Hoge Raad centraal staat. Een belangrijk 'neveneffect' van deze aandacht is dat we inmiddels goed zicht hebben op de (mogelijke) functies van art. 6:212. Paragraaf 6 neemt ons mee terug naar 20I2: waar staan we op dit moment? Staan de huidige ontwikkelingen in de sleutel van beperking of juist groei? Dat is een relevante vraag omdat de aandacht voor het thema in de literatuur voor de verrijkingsactie sinds enkele jaren lijkt te zijn verslapt. Is het debat in de literatuur doodgebloed of heeft de Hoge Raad inmiddels de rust doen weerkeren? Tegelijkertijd wordt er in de doctrine voor gepleit om meer werk te maken van voordeelsafdracht waarbij het verarmingsvereiste ter discussie wordt gesteld. ${ }^{817}$ In paragraaf 7 maken we dan een eindbalans op. Eén verontschuldiging is reeds nu op haar plaats: het is in het bestek van een preadvies met een beperkte omvang als dit niet mogelijk om volledigheid te betrachten en alle relevante literatuur en rechtspraak recht te doen. ${ }^{818}$ Maar laten we bij het begin beginnen: de lotgevallen van de Limburgse broers Te Poel.

\section{Van Quint-Te Poel-formule naar een algemene verrijkingsactie}

5. Broers schrijven geschiedenis $\mathrm{Zij}$ spelen de hoofdrol in een van de bekendste verhalen uit het Nederlandse burgerlijk recht. Hubertus te Poel sloot met aannemer Quint een overeenkomst voor de bouw van twee winkelpanden met bovenwoningen in Heerlen. Op zeker moment bleek Hubertus niet in staat te betalen; aannemer Quint kon zijn onbetaalde rekeningen niet op hem verhalen. De gebouwde panden bleken, omdat de grond eigendom was van broer Heinrich, door natrekking eigendom te zijn geworden van Heinrich te Poel. Omdat Quint met hem echter geen overeenkomst had gesloten, kwam onder meer een actie uit ongerechtvaardigde verrijking in beeld. De Hoge Raad wilde in zijn aan deze zaak gewijde arrest voor het oude recht echter niet weten van een algemene verrijkingsactie: ${ }^{819}$

8I7 Zo stelt J.G.A. Linssen, 'Ongerechtvaardigde verrijking', WPNR 6472 (2002), p. 67 dat we nog altijd geen volwaardig verrijkingsrecht hebben. In dat verband pleit hij ervoor de schade-eis te schrappen.

8I8 Ik leun duidelijk op bepaalde bronnen en heb de rijke verdere literatuur over dit thema niet stelselmatig kunnen verwerken. Daardoor komt ook de rechtshistorie er bekaaid van af. Veel materiaal is verwerkt in onder meer F.B. Brandsma, 'Derdenverrijking', RMThemis I994, p. 25I e.v., H.C.F. Schoordijk, Onverschuldigde betaling en ongerechtvaardigde verrijking bij zogenoemde driehoeksverhoudingen, Kluwer, Deventer 1999, E.J.H. Schrage, 'Over de verbintenis uit ongerechtvaardigde verrijking', in: Onderneming en 10 jaar Nieuw Burgerlijk recht (S.C.J.J. Kortmann e.a. (red.)), Kluwer, Deventer 2002, p. 62I e.v., D. Gerdes, Derdenverrijking, diss. Groningen, 2005 en J.W.M.K. Meijer, Ongerechtvaardigde verrijking, diss. Rotterdam, Sdu Uitgevers, Den Haag 2007.

8I9 HR 30 januari I959, NJ I959, 548 (DJV) (Quint/Te Poel). 
'O. dat het middel in de eerste plaats stelt, dat het B.W. den regel inhoudt, dat op een ieder die zonder wettigen grond ten koste van vermogen van een ander is verrijkt, een verbintenis rust om dien ander schadeloos te stellen tot het bedrag waarmede hij is verrijkt;

dat een rechtsregel van dezen inhoud niet in het Wetboek is opgenomen, doch eiseres meent, dat uit een aantal wetsbepalingen, waarin de wetgever zich klaarblijkelijk heeft laten leiden door de overweging, dat ongerechtvaardigde verrijking moet worden voorkomen, kan worden afgeleid dat de genoemde regel algemene gelding heeft;

dat echter uit deze artikelen niet volgt, dat het genoemde gezichtspunt naar het oordeel van den wetgever onder alle omstandigheden beslissend moet zijn en het achterwege laten van een algemenen regel in den geest van art. 2987 van het Ontwerp I820 op het tegendeel wijst;

dat niet onmogelijk moet worden geacht, dat de wetgever zich van het geven van een algemenen regel heeft onthouden omdat de toepassing daarvan in sommige gevallen tot ongewenste resultaten zou leiden, waarbij in het bijzonder kan worden gedacht aan de mogelijkheid, dat een schuldeiser zich langs dezen weg boven andere schuldeisers zou bevoordelen of aan de mogelijkheid, dat iemand wien tegen zijn wil een vermogensrechtelijk voordeel is opgedrongen, verplicht zou worden dit door betaling van een geldsom ongedaan te maken;

dat eiseres zich bij de mondelinge toelichting heeft beroepen op een traditie die in Frankrijk en ten onzent vóór de invoering van de codificatie zou hebben bestaan; $;^{820}$

dat zich inderdaad het geval laat denken, dat een ander onder het vroegere recht algemeen aanvaarde rechtsregel, welke door het Wetboek nòch uitdrukkelijk aanvaard, noch uitdrukkelijk verworpen is, na de invoering van het Wetboek blijft voortleven en deze regel alsdan krachtens de traditie als geldend recht moet worden aanvaard;

dat zodanig geval zich echter te dezen niet voordoet;

dat immers, daargelaten of het vóór de invoering van het Wetboek de gangbare opvatting is geweest, dat naast de bronnen van verbintenis die het Romeinse recht kende, de ongerechtvaardigde verrijking als zelfstandige bron van verbintenis moet worden erkend, deze traditie zich in ieder geval na de invoering van het Wetboek niet heeft voortgezet; (...).'

Vervolgens liet de Hoge Raad wel ruimte om een eventuele verbintenis aan te nemen voor zover deze in het stelsel van de wet zou passen en zou aansluiten bij wél uitdrukkelijk in de wet geregelde gevallen, doch in de zaak van Heinrich te Poel en

820 Kritisch hierover is Asser-Hartkamp/Sieburgh 6-IV, nr. 454 en 457. 
Quint leverde ook dat niets op omdat naar het oordeel van de Raad een recht op vergoeding van een aannemer jegens de eigenaar van de grond in het concrete geval zich niet zou verdragen met specifieke regelingen met betrekking tot het recht op vergoeding van een bezitter of een huurder jegens de eigenaar. Waarom zou een aannemer verdienen wat de wet hen onthoudt?

6. Wat beweegt de Hoge Raad? Uit de geciteerde overwegingen blijkt niet alleen dat de Hoge Raad geen algemene actie wilde aannemen, maar komt ook in beeld waarom hij dat niet wenste. Hij vreesde duidelijk ongewenste resultaten van een algemene actie, waarbij hij nadrukkelijk noemde de mogelijkheid, dat een schuldeiser zich op deze manier boven andere schuldeisers zou bevoordelen en de mogelijkheid, dat iemand die tegen zijn wil een vermogensrechtelijk voordeel is opgedrongen, verplicht zou worden dit door betaling van een geldsom ongedaan te maken. We herkennen hier elementen die ook in het debat over art. 6:2I2 en de rechtspraak van de Hoge Raad sinds 1992 nog centraal staan. Hoewel de Raad een algemene actie dus afwees, liet hij desalniettemin wel ruimte voor een vordering ter zake van ongerechtvaardigde verrijking buiten specifiek in de wet geregelde gevallen wanneer zij tenminste 'in het stelsel van de wet past en aansluit bij de wèl in de wet geregelde gevallen'. Deze 'techniek', later niet voor niets 'Quint-Te Poel-formule' genoemd, dwingt de rechter echter om het wettelijk systeem tegen het licht te houden. Dat gaf de Hoge Raad in het concrete geval vervolgens toch aanleiding de aannemer een vordering te ontzeggen. ${ }^{82 \mathrm{I}}$

7. Principekwestie of wetgevingstechniek? Waar het oude recht dus geen algemene verrijkingsactie kende, slaat het huidige BW duidelijk een andere toon aan. Dat betekent echter niet dat art. 6:212 er zonder slag of stoot is gekomen. ${ }^{822}$ Integendeel. Het begon allemaal, betrekkelijk kort na de Tweede Wereldoorlog, met Meijers' Vraagpunt 18 dat de Tweede Kamer het volgende voorlegde:

'Moet in een algemeen artikel worden bepaald, dat hij, die zonder voldoende rechtsgrond ten koste van een ander is verrijkt, verplicht is de door die ander geleden schade tot ten hoogste het bedrag der verrijking te vergoeden of moet de wet zich bepalen tot het noemen van enkele bijzondere gevallen, waarin deze vordering wordt toegelaten?'

De regering suggereerde een bevestigend antwoord op de eerste vraag en baseerde dat onder meer op het feit dat niet alleen het oud-vaderlandsche recht een algemene vordering kende, maar dat hetzelfde geldt voor nieuwere wetboeken (Duitsland, Italië, Zwitserland, Griekenland) terwijl van ernstige bezwaren bij de toepassing ervan in die stelsels niet zou zijn gebleken. Ook de praktijk van dat moment was

82I Kritisch op dit punt is G.E. van Maanen, 'De mythe van Quint/te Poel. Een herwaardering van Diephuis en Opzoomer en de ontmaskering van een overgewaardeerde uitspraak', Groninger Opmerkingen en Mededelingen 2008, p. 33 e.v.

822 Zie E.J.H. Schrage, Verbintenissen uit andere bron dan onrechtmatige daad of overeenkomst, Mon. Nieuw BW B-53, 2e druk, Kluwer, Deventer 2009, nr. go e.v. 
de regering een doorn in het oog. De Hoge Raad wenste de vordering immers niet zonder wettelijke basis toe te laten: ${ }^{823}$

'Hij wringt echter verschillende gevallen, waarin het wenselijk zou zijn degene ten koste van wie de ongerechtvaardigde verrijking heeft plaats gevonden een vordering tot restitutie te geven, onder andere artikelen, waaruit streng genomen de vordering niet af te leiden valt.'

In de Vaste Commissie voor Privaatrecht en Strafrecht van de Tweede Kamer heerste echter twijfel. ${ }^{82}$ Is er werkelijk behoefte aan een uitdrukkelijke algemene actie? Kunnen alleen zo bevredigende resultaten worden geboekt? Is het niet beter af te wachten met codificatie tot de vereisten nader in literatuur en rechtspraak zijn uitgekristalliseerd? Naar het oordeel van de regering zou niet-erkenning echter een 'ernstige leemte in ons recht' scheppen. ${ }^{825}$ De Kamercommissie was nog niet meteen om: ${ }^{826}$

'Een deel van de commissie meent, dat aangezien de actie wegens ongerechtvaardigde verrijking slechts een aanvullende rol zal spelen, tegen invoering daarvan geen bedenking bestaat, al zal van deze veiligheidsklep zeer zelden gebruik worden gemaakt. Een ander deel der commissie is, in verband met de werking van artikel I40I B.W., niet overtuigd, dat een dergelijke veiligheidsklep noodzakelijk is, en acht het opnemen van overbodige artikelen in de wet onjuist.'

(Ook) uit het verdere verloop kan worden afgeleid dat de verdeeldheid niet zozeer op het principe betrekking heeft (zo is 'buiten twijfel, dat niemand, verrijking zonder grond ten koste van een ander ongemoeid wil laten ${ }^{827}$ ) maar veeleer op de wijze waarop het moet worden geregeld in het nieuwe wetboek. Zou men zich moeten beperken tot een regeling van bijzondere gevallen of zou een algemeen artikel de voorkeur verdienen? De laatste optie zou gewrongen constructies en gekunstelde redeneringen voorkomen en ook een sluitend systeem opleveren: ${ }^{828}$

'En wat kan er niet in de toekomst aan twijfelgevallen bijkomen! Wij kunnen niet alles vooruitzien en moeten ons hoeden voor lacunes welke in de toekomst kunnen opkomen.'

Zo bekeken ging het eerder om een kwestie van wetgevingstechniek dus, niet om een grote inhoudelijke koerswijziging: ${ }^{829}$

823 Toelichting op het Vraagpunt, Parl.Gesch. Boek 6, p. 823.

824 Voorlopig Verslag II, Parl.Gesch. Boek 6, p. 824.

825 Memorie van Antwoord II, Parl.Gesch. Boek 6, p. 824.

826 Mondeling Overleg (2846), Parl.Gesch. Boek 6, p. 826.

827 Parl.Gesch. Boek 6, p. 826 .

828 KVP-Kamerlid Lemaire, Parl.Gesch. Boek 6, p. 827.

829 PvdA-Kamerlid Tendeloo, Parl. Gesch. Boek 6, p. 827. 
'Ook naar mijn mening zal dit artikel alleen maar een beperkte betekenis kunnen krijgen; men moet er niet al te veel verwachtingen van hebben. Dat doe ik ook niet. Ik zie het terrein ook zeer beperkt. Ik zie het voorstel van de Minister om één algemeen artikel als een zekere afronding van het systeem in de wet op te nemen als juist en dit lijkt mij op zijn plaats.'

In het Ontwerp Meijers werd uiteindelijk voorgesteld een algemene bepaling op te nemen. $\mathrm{Zij}$ is: ${ }^{830}$

'ook om deze reden gewenst, dat het niet wel mogelijk zou zijn door bijzondere bepalingen in alle gevallen, waarin het beginsel toepassing moet vinden, te voorzien. De moderne wetboeken bevatten eveneens een regeling van de ongerechtvaardigde verrijking.'

Afgezien van de verplaatsing van de oorspronkelijke tweede zin naar de latere leden 2 en 3 van het uiteindelijke art. 6:2I2 verschilt de voorgestelde bepaling niet van art. 6:2I 2 zoals we dat thans kennen.

8. Algemeen deel Het komt er dus op neer dat art. 6:212 gekunstelde redeneringen en 'een ernstige leemte in ons recht' moet voorkomen. Het systeem is daarmee sluitend gemaakt, waar een andere wetgevingstechniek (het opnemen van bijzondere bepalingen voor specifieke gevallen) dat nu juist niet kan waarborgen; men kan immers niet door bijzondere bepalingen in alle gevallen, waarin het beginsel toepassing moet vinden, voorzien. Dat neemt niet weg dat de wetgever naast art. 6:2I2 wel degelijk ook nog bijzondere verrijkingsbepalingen heeft opgenomen. In dat verband heeft art. 6:2I2 als niet onbelangrijke functie: ${ }^{83}$

'dat aldus op één centrale plaats een regeling voorkomt van de algemene problematiek waarnaar op andere plaatsen kan worden verwezen, zodat niet telkens afzonderlijke bepalingen nodig zijn.'

Hier vervult art. 6:212 dan een 'algemeen deel'-functie. ${ }^{832}$ Eerst en vooral gaat het daarbij om de vereisten die men aan een succesvolle art. 6:2I2-vordering mag stellen.

9. Globale blik op de vereisten Tekst en toelichting leren dat sprake moet zijn van:

830 Toelichting Meijers, Parl.Gesch. Boek 6, p. 829.

83I MvA II, Parl.Gesch. Boek 6, p. 834. Zie R.D. Vriesendorp, 'Ongerechtvaardigde verrijking', hoofdstuk ${ }_{3} 3$ in: Verbintenissen uit de wet en Schadevergoeding, deel 5 in de Studiereeks Burgerlijk Recht, 6e druk, Kluwer, Deventer 20I2, nr. 3 I8.

832 Ik wijs nog op art. 75 lid 3 Wet Bodembescherming dat betrekking heeft op het geval van ongerechtvaardigde verrijking bij sanering van de bodem door de Staat. Zie onder meer HR 28 april 2000, NJ 2000, 690 (ARB) (Dordrecht/Stokvast BV), HR I5 maart 2002, NJ 2004, I26 (WMK) (Daams/Staat), HR I3 september 2002, NJ 2003, 400 (WMK) (Staat/Lodewijk Geveke Bouw BV) en HR 25 maart 2005, NJ 2005, 4I3 (CJHB) (Bedum/Huizingh). 
- een verrijking van de een;

- verkregen ten koste van een ander, degeen die vergoeding van zijn schade eist: er is dus een verarming van eiser nodig die in zeker verband staat tot de verrijking van de gedaagde;

- terwijl de verrijking ongerechtvaardigd is. ${ }^{83}$

De problemen liggen niet zozeer op het vlak van verrijking en verarming als zodanig - in ieder geval geldt dat een ruime uitleg gebruikelijk is - doch veeleer op het vlak van de andere vereisten. Wat het verband tussen verrijking en verarming betreft, geeft de toelichting bijvoorbeeld nauwelijks houvast: ${ }^{834}$

'Het is niet mogelijk in de wet een criterium te geven ter beantwoording van de vraag of in een bepaald geval de verrijking al dan niet ten koste van een ander is geschied; dit moet aan de rechtspraak worden overgelaten.'

Dat zien we ook terug in de (kritiek op de) rechtspraak van de Hoge Raad. ${ }^{835}$ De lastigste voorwaarde is ongetwijfeld dat de verrijking ongerechtvaardigd is. Dat is, zo blijkt uit de toelichtende stukken, niet het geval wanneer zij het gevolg is van een rechtshandeling (waarbij te denken valt aan ongelijkwaardige prestaties bij een koop) of wanneer zij door de wet wordt gesanctioneerd. ${ }^{836}$ In dit verband kan art. 3:I20 lid I als illustratie dienen: de bezitter te goeder trouw komen de afgescheiden vruchten toe. Aan de andere kant is er bij originaire vormen van eigendomsverkrijging soms reden voor een vordering ter zake van ongerechtvaardigde verrijking. De bepalingen omtrent verbinding, vermenging en zaaksvorming geven slechts uitsluitsel over de eigendomsvraag maar sluiten een vergoeding niet uit: ${ }^{837}$

'Indien een verrijking het gevolg is van een wettelijke regeling, hangt het derhalve van de strekking van de regeling af, of er voor een vordering uit ongerechtvaardigde verrijking plaats is of niet. ${ }^{838}$

Hier stuiten we op een bijzonder kenmerk van de verrijkingsactie: bij de kernvraag naar de ongerechtvaardigdheid van de verrijking wordt men (veelal) gedwongen te kijken naar het wettelijk systeem, en dat, op zoek naar een legitimatie, 'af te tasten', een term die Schoordijk in dit verband heeft gemunt. ${ }^{839}$ De vraag is derhalve of het systeem de verrijking sanctioneert. Die vraag is echter makkelijker geformuleerd dan beantwoord.

833 Uitvoeriger hierna nr. I5 e.v.

834 TM, Parl.Gesch. Boek 6, p. 829 .

835 Hierna nr. 38 en 39.

836 TM, Parl.Gesch. Boek 6, p. 829-830.

837 TM, Parl.Gesch. Boek 6, p. 830.

838 TM, Parl.Gesch. Boek 6, p. 830.

839 Zie onder veel meer H.C.F. Schoordijk, 'Ongerechtvaardigde verrijking in een drie-partijen-verhouding', NJB I997, p. I750. 
Io. Illustratiemateriaal Wanneer de wet in bepaalde gevallen tot een vermogensverschuiving leidt, zal veelal aangenomen mogen worden dat dan ook de verrijking die daarvan het gevolg is, gerechtvaardigd is. Dat geldt ook in die gevallen dat zij geheel buiten toedoen van de verarmde plaatsvond, zij het dat daarop ook uitzonderingen denkbaar zijn. Ter verduidelijking van een en ander worden daarbij in de parlementaire stukken enkele voorbeelden gegeven die in de doctrine met instemming zijn begroet en worden overgenomen: ${ }^{80}$

- in geval van natrekking en vermenging mag worden aangenomen dat de verrijking in beginsel ongerechtvaardigd is, zodat er verbintenisrechtelijk een correctie plaatsvindt op de goederenrechtelijke verkrijging;

- in geval van verkrijging van een goed of een voordeel ten koste van een ander op grond van een regel van bescherming van de goede trouw (denk aan art. 3:86; bescherming van de derde te goeder trouw die verkrijgt van een beschikkingsonbevoegde vervreemder) ligt in de aard daarvan opgesloten dat de verrijking niet ongerechtvaardigd is; degene die ten koste van de oorspronkelijke rechthebbende zijn recht verkrijgt, is deze dus niets verschuldigd;

- indien iemand voordeel, een tegenprestatie bijvoorbeeld, verkrijgt doordat hij andermans goed aan een derde overdraagt die op grond van zijn goede trouw wordt beschermd (denk weer aan art. 3:86), is er volgens de toelichting veel voor te zeggen dat hij ongerechtvaardigd is verrijkt voor zover hij zelf het goed aan de rechthebbende had moeten afgeven; ${ }^{84 \mathrm{I}}$

- indien iemand een voordeel verwerft als gevolg van het verstrijken van een verval- of verjaringstermijn is deze verrijking niet ongerechtvaardigd;

- indien iemand een recht verliest aan een ander op grond van een onjuist gewezen rechterlijke uitspraak die in kracht van gewijsde is gegaan, zou, aldus opnieuw de toelichting, geen verrijkingsvordering zijn toegelaten. Of men in zo'n geval nog op de beslissing kan terugkomen, is een vraag die moet worden beantwoord binnen het stelsel van buitengewone rechtsmiddelen.

II. Inpassen en vaststellen Relevant voor de vraag wat er nu precies in het kader van art. 6:2I2 dient te gebeuren, lijkt ook de passage waarin de regering een voorstel van het Nederlands Genootschap voor Bedrijfsjuristen om in de tekst een (nadere) beperking op te nemen afwijst: ${ }^{842}$

'Het gaat noch om een bepaalde mate van ongerechtvaardigdheid noch ook steeds om het opvullen van leemten in wetsbepalingen die soortgelijke gevallen regelen, maar vooral om een zorgvuldige inpassing in de in een bepaald geval in aanmerking komende rechtsregels c.q. - zoals bij natrekking en vermenging - om de vaststelling van de werkelijke strekking daarvan.'

840 MvA II, Parl.Gesch. Boek 6, p. 833.

84I Kritisch echter B.W.M. Nieskens-Isphording en A. van der Putt-Lauwers, 'Derdenbescherming en ongerechtvaardigde verrijking', WPNR 6496 (2002), p. 488 e.v.

842 MvA II, Parl.Gesch. Boek 6, p. 834 . 
Inpassen en vaststellen, daar komt het dus op aan. Daarmee wordt duidelijk dat de context van het wettelijk systeem cruciaal is. ${ }^{843}$ Niet alleen komt het erop aan vast te stellen, in gevallen waarin een verrijking in eerste instantie op de wet is terug te voeren, wat de wet inhoudt, maar mocht de conclusie zijn dat de wet niet zonder meer de vermogensverschuiving legitimeert, dan zal ook nog naar een eindresultaat moeten worden gestreefd dat aansluiting vindt bij andere door het systeem geregelde gevallen.

I2. Of is (strijd met) de wet een uitzondering? De context van het wettelijk systeem is dus cruciaal. Dat blijkt ook tijdens de behandeling in de Eerste Kamer. Daar rees de vraag of de woorden 'voor zover redelijk' niet beter konden worden vervangen door 'tenzij dit in strijd is met de inhoud of strekking van een andere wettelijke regeling'. Dat zou volgens de Eerste Kamercommissie wenselijk zijn vooral in gevallen waarin het verrijkingsartikel niet als algemene regeling (algemeen deel) ten opzichte van een bijzondere bepaling functioneert, ${ }^{84}$ maar (bij gebreke van zo'n bijzondere bepaling) juist een zelfstandig bestaan leidt. Uit de Memorie van Antwoord zou, zo werd in de senaat betoogd, blijken dat ook de regering poogt te voorkomen dat de verrijkingsbepaling op een zodanige wijze zou worden toegepast dat een andere wettelijke regeling wordt doorkruist. Daarbij noemt de commissie, daartoe aangezet door de hiervoor ${ }^{845}$ al genoemde voorbeelden, de regelingen met betrekking tot verjaring en verval, derdenbescherming en met betrekking tot de buitengewone rechtsmiddelen. Het zou volgens de commissie de voorkeur verdienen de tekst aan te passen, zodanig dat dan tevens zou zijn aangegeven 'als laatste overblijfsel van subsidiariteit' dat bij strijd tussen de verrijkingsbepaling en een andere wetsbepaling die laatste in beginsel voorrang heeft. ${ }^{846}$ De regering vreesde echter juist bij het overnemen van het tekstvoorstel een te ruim toepassingsbereik van de verrijkingsactie en meende overigens dat de woorden 'voor zover redelijk' niet kunnen worden gemist, omdat daarmee opgedrongen prestaties kunnen worden voorkomen. ${ }^{847}$ Dat kan niet worden overgelaten aan art. 6:212 lid 2 en lid $3^{848}$ of aan art. 6:Iog dat de rechter die schadevergoeding toewijst een matigingsbevoegdheid toekent maar te terughoudend is geformuleerd. ${ }^{849}$ Waar het mij nu om gaat, is dat (ook) hier blijkt dat de wet of het wettelijk systeem geen uitzonderingsbepaling opleveren maar een inherent aan elke toepassing van art. 6:212 verbonden toetsingsmoment inhouden.

843 Zie bijvoorbeeld HR 28 oktober 20II, NJ 20I2, 495 (F.M.J. Verstijlen) (Van Hees q.q./CohenVisser).

844 Hiervoor nr. 8.

845 Hiervoor nr. Io.

846 Eindverslag I, Parl.Gesch. Boek 6, p. 836.

847 Hierna nr. 23. Vaker genoemd (bijvoorbeeld door Vriesendorp 2012, nr. 317) is het voorbeeld van de schilder die ongevraagd het verveloze huis van een afwezige schildert. Normaal gesproken zal daarvan een verrijking voor de eigenaar het gevolg zijn tegen een verarming bij de schilder. Ook het verband tussen verrijking en verarming is niet problematisch. De verrijking is ongerechtvaardigd, nu zij niet door enige rechtshandeling of wetsbepaling wordt gelegitimeerd. Bij toewijzing van art. 6:212 wordt ongewenste bemoeizucht echter beloond en wordt de eigenaar van het pand een prestatie opgedrongen. Dat kan in de tekstuele tournure worden voorkomen.

848 Hierna nr. 24.

849 Eindverslag I, Parl.Gesch. Boek 6, p. 836. 
Het is niet zo dat de verrijkingsactie bij uitzondering wegens doorkruising van het systeem wordt afgewezen; bij de vraag of een verrijkingsactie slaagt, zal steeds het wettelijk systeem moeten worden 'afgetast'. Dat geeft aan de wet en het wettelijk systeem een geheel andere plaats en status.

13. Laatste woord? Niet zonder betekenis is overigens dat in de toelichting nadrukkelijk wordt aangegeven dat met het opnemen van een algemene regeling de rechtsontwikkeling niet is gestuit: ${ }^{850}$

'Uiteraard heeft het onderhavige artikel niet de strekking alle vragen die met betrekking tot de ongerechtvaardigde verrijking kunnen rijzen, tot een oplossing te brengen: rechtspraak en wetenschap zullen een andere omlijsting aan het beginsel moeten geven.'

De wetgever zet daarmee zijn geld op literatuur en rechtspraak, hetgeen door critici van de jurisprudentiële ontwikkelingen na 1992 als belangrijke oorzaak van 'de ellende' wordt gezien. ${ }^{851}$ Dat hier overigens verschillende accenten kunnen worden gelegd, blijkt nog eens uit een onderzoek van het Nieuw BW-archief dat in beeld heeft gebracht dat een aanvankelijk veel uitvoeriger toelichting drastisch is ingekort juist omdat men vreesde dat deze de rechtspraktijk in de weg zou zitten..$^{852}$ De vraag wat het beste is voor de rechtspraktijk - strak regelen en inkaderen of juist de ruimte laten aan doctrine en rechterlijke macht? -, zal niet door iedereen op dezelfde manier beantwoord worden.

14. Een bijzondere algemene actie Wat levert deze korte excursie nu op? Hoewel de parlementaire geschiedenis van art. 6:2I2 natuurlijk vooral geschiedenis is, zegt zij wel degelijk iets over de structuur van de actie en zijn ook de indicaties over de toepassing ervan aan de hand van voorbeelden relevant. ${ }^{853}$ Uit de totstandkomingsgeschiedenis valt af te leiden dat art. 6:212 een tweetal 'rollen' wordt toebedeeld:

- ten eerste moet art. 6:212 het wettelijk systeem vervolmaken; het vult eventuele leemten op;

- ten tweede biedt het een algemene regeling ('algemeen deel') waarnaar kan worden verwezen wanneer de wetgever elders in het BW een specifieke verrijkingsbepaling wenst op te nemen..$_{54}$

850 TM, Parl.Gesch. Boek 6, p. 83i.

$85 \mathrm{I}$ Zie bijvoorbeeld Nieskens-Isphording 1998 , p. 98.

852 D.M.A. Gerdes, 'Ongerechtvaardigde verrijking: een onderzoek in het NBW-archief', NTBR 2006, p. 5 e.v.

853 In deze zin al M.H. Wissink, 'De emancipatie van artikel 6:2I2 BW', in: Aspecten van ongerechtvaardigde verrijking, preadviezen voor de Vereniging voor Burgerlijk recht, Kluwer, Deventer 2002, nr. 5I, p. 6I.

854 Hiervoor nr. 8. 
Vooral de eerste trekt onze aandacht. Waar de Hoge Raad in dit verband de oplossing immers zocht in de Quint-Te Poel-formule - geen algemene actie maar 'inpassen en aansluiten bij de wet' -, geeft de wetgever de actie nu juist een zelfstandige plaats. Daarmee haalt de wetgever haar op het eerste gezicht uit de marge en tilt hij haar daarmee naar een hoger plan. Bij nader inzien lijkt dit beeld echter overdreven, omdat het uiteindelijk ook bij de toepassing van de algemene actie gaat om 'een zorgvuldige inpassing in de in een bepaald geval in aanmerking komende regels' ${ }^{855}$ Ik kan daarom met instemming Wissink aanhalen: $:^{85}$

'Gezien de parlementaire geschiedenis kan de vraag rijzen of het nu werkelijk zoveel uitmaakt om in plaats van de Quint-Te Poel-benadering een algemene bepaling te hebben die als een soort sluitstuk op het systeem fungeert. (...) Zo bezien lijkt de parlementaire discussie over nut en noodzaak van de opname van een algemene verrijkingsbepaling er een van het type: is het glas half vol of is het half leeg?'

Ook al heeft de wetgever de actie als zelfstandige algemene actie erkend, de toepassing ervan houdt per definitie in dat onder de noemer van de vraag of de eventuele verrijking ongerechtvaardigd is het wettelijk systeem moet worden afgetast en moet worden doorgrond. Dat is weliswaar niet hetzelfde als zeggen dat de bepaling restrictief moet worden toegepast, ${ }^{857}$ zij moet immers serieus worden genomen en in haar rol 'vol' worden benut, maar uit de aard der zaak volgt dat het systeem moet worden beoordeeld en doorgrond..$^{8} 8$ Dat makt deze actie nu juist anders dan andere. Laten we haar nu wat beter bekijken.

\section{Art. 6:212 beter bekeken}

I5. In een notendop In het stelsel van het BW is de verrijkingsactie een schadevergoedingsactie, geen ongedaanmakingsactie; zij strekt tot vergoeding van de door de verarmde geleden schade, niet tot restitutie. ${ }^{859}$ Dat brengt onder meer ook mee dat afdeling 6.I.Io die algemene regels geeft met betrekking tot wettelijke verplichtingen tot schadevergoeding bijvoorbeeld over begroting, causaal verband, eigen schuld etc. van toepassing is. Het recht op schadevergoeding is uiteraard pas aan de orde wanneer aan de in art. 6:212 gestelde voorwaarden is voldaan. Kort en goed gaat het daarbij om:

- een verrijking van de een;

- een verarming van de ander;

855 MvA II, Parl.Gesch. Boek 6, p. 834 .

856 Wissink 2002, nr. 5I, p. 6I.

857 Dat kan Vranken I 998 en Wissink 2002, nr. 52 worden toegegeven.

858 Dat hoort nu eenmaal bij de rol van de bepaling die, in zoverre is er dus wel sprake van terughoudendheid, niet te pas en te onpas met succes kan worden ingeroepen.

859 Asser-Hartkamp/Sieburgh 6-IV, nr. 479 en Vriesendorp 20I2, nr. 3I9 en 290. 
- causaal verband tussen verrijking en verarming ('ten koste van');

- ontbreken van een rechtvaardiging ('ongerechtvaardigd').

Is aan deze voorwaarden voldaan dan is de verrijkte 'voor zover dat redelijk is', ook dat is dus nog een toetsingsmoment, verplicht de schade van de verarmde te vergoeden. Of er daadwerkelijk recht bestaat op vergoeding is afhankelijk van genoemde voorwaarden. De omvang van de vergoeding wordt primair bepaald door de verarming, het is immers een schadevergoedingsactie, maar ook door de verrijking: de verrijkte kan niet worden verplicht méér te vergoeden dan het bedrag dat gemoeid is met zijn verrijking. We spreken hier wel van een 'dubbel plafond'. Bij de vaststelling van de schade en de omvang van de vergoeding ter zake is dan afdeling 6.I.Io relevant, maar daaraan vooraf gaat de vraag of vergoeding redelijk is, althans vergoeding vindt alleen plaats 'voor zover dat redelijk is' ${ }^{860}$

I6. Schadevergoeding; geen ongedaanmaking De verrijkingsactie leidt tot vergoeding van de schade die de verarmde als gevolg van de ongerechtvaardigde verrijking lijdt, niet tot restitutie of ongedaanmaking van de ongerechtvaardigde verrijking als zodanig. ${ }^{86 \mathrm{I}} \mathrm{Zij}$ kan echter zeer wel samenlopen met een 'echte' ongedaanmakingsactie. ${ }^{862}$ Daarbij kan onder meer worden gedacht aan de actie uit onverschuldigde betaling (afdeling 6.4.2 die bijvoorbeeld na vernietiging van een rechtshandeling aan de orde is) en de ongedaanmaking van een reeds verrichte prestatie bij ontbinding wegens wanprestatie (art. 6:27I e.v.), een rechtsmiddel dat naar huidig Nederlands recht anders dan vernietiging (art. 3:53 lid I) geen terugwerkende kracht heeft (art. 6:269). Beide ongedaanmakingsregelingen voorzien ook in een oplossing voor de ongedaanmaking van prestaties waarvan de aard zich verzet tegen restitutie als zodanig. Zowel art. 6:272 (ongedaanmaking na ontbinding) als art. 6:2 Io lid 2 kiest dan voor waardevergoeding, eigenlijk om te voorkomen dat de ontvanger van de prestatie ongerechtvaardigd zou worden verrijkt doordat hij zijn eigen prestatie zou terugkrijgen en zelf niets hoeft te vergoeden. ${ }^{86_{3}}$ De meerwaarde ten opzichte van art. $6: 212$ is daarin gelegen dat niet vereist is dat de wederpartij schade heeft geleden. ${ }^{864}$

86o Dat is ook weer gemakkelijker gezegd dan gedaan: verschillende zaken (neem bijvoorbeeld de vraag wat de invloed is van eventuele 'eigen schuld' van de verarmde) kunnen zowel onder de noemer van afdeling 6.I.Io (in dit geval art. 6:Ior (eigen schuld)) als onder de noemer van de nadere redelijkheidstoets ('voor zover redelijk') worden afgehandeld. Of de in de hoofdtekst genoemde volgorde dus steeds goed kan worden aangehouden, is de vraag. Zie hierna nr. 23 .

86I Kritisch in dit verband A.S. Hartkamp, 'Ongerechtvaardigde verrijking naast overeenkomst en onrechtmatige daad (I)', WPNR 6440 (200I), p. 314-3I5 die ook vraagtekens plaatst bij de toepassing van afdeling 6.I.Io. Zo vraagt hij zich af of bepalingen als art. 6:98 zich wel lenen voor een vergelijkbare toepassing als bij onrechtmatige daad. Het probleem zit voor hem in het feit dat ongerechtvaardigde verrijking 'eigenlijk' geen grond voor schadevergoeding is, maar voor ongedaanmaking van een verrijking.

862 Asser-Hartkamp/Sieburgh 6-IV, nr. 475.

863 In art. 6:2 Io lid 2 wordt daarbij overigens in de tekst op een vergelijkbare manier als in art. 6:2I2 gepoogd te voorkomen dat prestaties worden opgedrongen. Zie Asser-Hartkamp/Sieburgh 6-IV, nr. 447 .

864 Zie Asser-Hartkamp/Sieburgh 6-IV, nr. 448 met vermelding van het in de toelichting genoemde geval van een verstekeling die is vervoerd in een niet volgeboekt vliegtuig. 
17. Basale regels voor de afwikkeling Is eenmaal een recht op schadevergoeding ex art. 6:2I2 ontstaan dan zijn op de afwikkeling ook een aantal algemene regels van toepassing. ${ }^{865}$ Zo geldt met betrekking tot de vraag of de verrijkte wettelijke rente verschuldigd is vanwege het niet (tijdig) nakomen van zijn op art. 6:2I2 gebaseerde schadevergoedingsverplichting het algemene regime van art. 6:II9 jo. afdeling 6.I.9, zodat verzuim van de schuldenaar vereist is. Anders dan bij niet-nakoming van een verplichting tot vergoeding van schade wegens wanprestatie of onrechtmatige daad is verzuim van rechtswege niet aan de orde. Omdat art. 6:83 sub b hier volgens de Hoge Raad toepassing mist, ${ }^{866}$ dient eerst een ingebrekestelling te worden uitgebracht: blijft nakoming binnen de daarin gestelde redelijke termijn uit, dan is verzuim een feit (art. 6:82 lid I) en gaat op dat moment derhalve de wettelijke rente lopen. Ook wat betreft de verjaring van de op art. 6:2I2 gebaseerde schadevergoedingsverplichting geldt het algemene regime voor schadevergoedingsverplichtingen van art. 3:310 lid I. Dit gaat uit van een korte termijn van 5 jaar te rekenen vanaf het moment dat de schuldeiser (de verarmde) zowel met de schade als met de daarvoor aansprakelijke persoon (de verrijkte) bekend is geworden. De rechtsvordering verjaart echter in ieder geval door verloop van 20 jaar na de gebeurtenis waardoor de schade is veroorzaakt. In de praktijk betekent dit dat de verjaringstermijn van 20 jaar begint te lopen op het moment van de verrijking. ${ }^{867}$

I8. Dubbel plafond Het in het wettelijk systeem gekozen karakter van een schadevergoedingsactie leidt ertoe dat de vergoeding ex art. 6:212 aan twee kanten beperkt is. Omdat het om schadevergoeding gaat, is in eerste instantie de verarming bepalend. Zonder verarming dus geen vergoeding, ook niet wanneer er wel een verrijking aan de andere kant plaatsvindt. ${ }^{868}$ De omvang van de vergoeding wordt echter niet alleen bepaald door de verarming en dus door de schade, maar ook door de verrijking: de verrijkte kan niet worden verplicht méér dan het bedrag dat gemoeid is met zijn verrijking te vergoeden. Is de verrijking minder groot dan de verarming dan komt 'slechts' het lagere met de verrijking gemoeide bedrag in beeld. In zoverre blijft de verarmde dan met zijn schade zitten, tenzij hij met succes een andere rechtsgrond weet aan te boren. Dit dubbele plafond heeft daarom ook consequenties voor de samenloopproblematiek: voor de verarmde kan het noodzakelijk zijn om een andere actie te benutten wil hij werkelijk zijn volledige schade vergoed krijgen. ${ }^{869}$ Daarbij denke men natuurlijk vooral aan een actie uit onrechtmatige daad.

19. Verrijking en verarming Art. 6:212 eist behalve een verrijking bij de een ook een verarming bij de ander. Wanneer is daarvan sprake? Hiervoor is al opgemerkt dat

865 Vriesendorp 2012, nr. 323 en 320.

866 HR 9 juli 20I0, NJ 20I0, 498 (ProAv Zuid-Holland NV/AVA BV).

867 Vriesendorp 2012, nr. 320.

868 Dit resultaat wordt in de doctrine echter wel ter discussie gesteld. Is het immers niet beter naar verrijkingsafdracht te streven dan naar schadevergoeding? Zie hierna nr. 55 .

869 Zie ook Asser-Hartkamp/Sieburgh 6-IV, nr. 480 die daarbij ook in discussie gaat met Van Boom 2002. 
een ruime benadering gebruikelijk is. ${ }^{870} \mathrm{Wat}$ de verrijking betreft, dient niet alleen te worden gedacht aan vermeerdering van de activa, maar ook aan vermindering van de passiva. ${ }^{871}$ Bij het eerste denke men aan hetverkrijgen van een goed, het ontvangen van een geldsom of van bepaalde diensten of het genot van een vermogensbestanddeel van een ander, bij het tweede bijvoorbeeld aan het wegvallen of verminderen van een schuld. Ook besparing van kosten kan een verrijking in de zin van art. 6:212 opleveren. ${ }^{872} \mathrm{Om}$ de verrijking te bepalen zal een vergelijking moeten worden gemaakt van het vermogen van de verrijkte vóór en na de gebeurtenis waarop de vordering berust. ${ }^{873}$ Voor de verarming geldt uiteraard eenzelfde ruimhartige benadering, zij vormt in wezen het spiegelbeeld van de verrijking, zodat van een verarming sprake is niet alleen bij vermindering van de activa, maar ook bij vermeerdering van de passiva. Dit betekent echter niet, zoals hiervoor ook al aan de orde kwam, ${ }^{874}$ dat de verrijking en de verarming steeds even groot zullen zijn. ${ }^{875}$ Mocht de verrijking kleiner zijn dan de verarming dan is de consequentie dat de verarmde langs de weg van art. 6:2I2 niet zijn volledige schade vergoed krijgt. Daarmee is, als gezegd, voor hem het belang bij een andere schadevergoedingsactie dan gegeven.

20. Causaal verband; 'ten koste van' Art. 6:2I2 vereist niet alleen een verrijking en een verarming, maar ook een verband tussen beide. De toelichting maakt ons, zoals eerder al aangegeven, ${ }^{876}$ op dit punt niet veel wijzer: ${ }^{877}$

'Het is niet mogelijk in de wet een criterium te geven ter beantwoording van de vraag of in een bepaald geval de verrijking al dan niet ten koste van een ander is geschied; dit moet aan de rechtspraak worden overgelaten.'

Het vereiste houdt in ieder geval niet in dat verarmde en/of verrijkte de verrijking hebben veroorzaakt. ${ }^{878}$ Denk aan de dief die gestolen apparatuur inbouwt in een aan mij toebehorende, eveneens door de dief gestolen auto. Waar het om gaat, is dat de verarmde een vordering heeft op degene die ten koste van hem is verrijkt. Het causaal

870 Nr. 9.

87I Asser-Hartkamp/Sieburgh 6-IV, nr. 46I en 463, Schrage 2009, nrs. I05 e.v., Van Maanen 200I, p. II e.v.

872 Zie bijvoorbeeld HR 5 september 2008, NJ 2008, 48I. De man heeft gedurende de periode waarin hij een affectieve relatie met de vrouw had, werkzaamheden verricht en uitgaven gedaan ten behoeve van de verbouwing van woonhuis annex winkel van de vrouw. Nadat de relatie is beëindigd, vordert de man voldoening van door hem gepleegde inspanningen en gedane uitgaven. Hij legt aan zijn vordering onder meer ongerechtvaardigde verrijking ten grondslag. Het hof overweegt dat slechts van verrijking sprake kan zijn als het pand door de verbouwing in waarde zou zijn gestegen. De Hoge Raad oordeelt echter dat van een ongerechtvaardigde verrijking van de vrouw ook sprake kan zijn indien en voor zover de uitgaven ten behoeve van de verbouwing, ook al heeft die verbouwing niet tot een waardestijging van het pand geleid, voor rekening van de man zijn gekomen en de vrouw zich die uitgaven aldus heeft bespaard.

873 HR 22 juni 2007, NJ 2007, 45I (De Haan BW/Hulshof en Kleinlugtenbelt).

874 Nr. I8.

875 Vriesendorp 20I2, nr. 3I2.

876 Nr. 9.

877 TM, Parl.Gesch. Boek 6, p. 829.

878 Vriesendorp 20I2, nr. 3 I3. 
verband is gelegen in de gebeurtenis waardoor de verrijking heeft plaatsgevonden. Het is niet vereist dat de verrijking 'onmiddellijk' ten laste van het vermogen van de verarmde heeft plaatsgevonden. ${ }^{879}$ Ongerechtvaardigde verrijking kan, zoals eerder al is aangegeven, ${ }^{880}$ ook aan de orde zijn wanneer de vermogensverschuiving optreedt door tussenkomst van een derde (indirecte verrijking), zij het dat in een dergelijk geval afhankelijk van de omstandigheden het ontbreken van causaal verband $^{881}$ of het ontbreken van een legitimatie (de verrijking is niet ongerechtvaardigd) aan een geslaagde actie in de weg kunnen staan. ${ }^{882}$

2I. Kern van de zaak De belangrijkste maar tevens lastigste voorwaarde voor vergoeding betreft juist de ongerechtvaardigdheid van de verrijking. Belangrijk omdat uiteindelijk in samenlevingen als de onze ontelbare vermogensverschuivingen en daarmee verarmingen en verrijkingen aan de orde zijn, maar buiten kijf is dat met de meeste daarvan niets mis is, zodat van schadevergoeding dan ook geen sprake kan zijn. ${ }^{883}$ Dat de verrijking ongerechtvaardigd is, is dan ook een essentiële beperking van het bereik van art. 6:2I2. Lastig is deze voorwaarde niet omdat onduidelijk is wat ermee wordt beoogd, wel omdat het niet eenvoudig is aan te geven wanneer een verrijking ongerechtvaardigd is. We beogen ermee aan te geven dat de verrijking niet door het wettelijk systeem gelegitimeerd is. Een legitimatie, een redelijke oorzaak, een rechtvaardigingsgrond ontbreekt. Wanneer zij precies ontbreekt, valt echter hooguit in abstracto en aan de hand van voorbeelden aan te geven, zoals in de doctrine ook pleegt te gebeuren. ${ }^{8{ }_{4}}$ Ook in de parlementaire stukken zijn dergelijke voorbeelden behandeld waarvan een aantal hiervoor ook is genoemd. ${ }^{885}$ Verdere invulling is in wezen overgelaten aan rechtspraak en literatuur die bij de beoordeling van concrete gevallen dan ook het wettelijk systeem dienen af te tasten op zoek naar een legitimatie. ${ }^{886}$ Grof gezegd ontbreekt zij wanneer de verrijking noch op een rechtshandeling berust noch krachtens wet mag worden behouden. Hiervoor is al gewezen op het voorbeeld van de ongelijkwaardige prestaties bij een koop, ${ }^{887}$ op art. 3:I20 lid I dat de bezitter te goeder trouw de afgescheiden vruchten doet toekomen en op de rol van de verrijkingsvordering bij originaire vormen van eigendomsverkrijging: 888

879 Asser-Hartkamp/Sieburgh 6-IV, nr. 462.

880 Nr. 3.

88I Vgl. HR 27 juni I997, NJ I997, 3 I9 (JH) (Setz/Brunings).

882 Asser-Hartkamp/Sieburgh 6-IV, nr. 462 en Vriesendorp 2012, nr. 313 die allebei ingaan op HR 30 september 2005, NJ 2007, I54 (JBMV) (Koker/Cornelius). Zie hierna nr. 53.

883 Asser-Hartkamp/Sieburgh 6-IV, nr. 465 en Vriesendorp 2012, nr. 310 en 314.

884 Asser-Hartkamp/Sieburgh 6-IV, nr. 465, Schrage 2009, nr. I43 en I49-I50, Vriesendorp 20I2, nr. 3 I4 en Van Maanen 200I, p. I7 e.v.

885 TM, Parl.Gesch. Boek 6, p. 829-830 en 833 (MvA II). Zie hiervoor nr. Io.

886 Van Maanen 200I, p. I7.

887 Nr. 9.

888 TM, Parl.Gesch. Boek 6, p. 830. 
'Indien een verrijking het gevolg is van een wettelijke regeling, hangt het derhalve van de strekking van de regeling af, of er voor een vordering uit ongerechtvaardigde verrijking plaats is of niet.'

Een enkele keer geeft de wetgever expliciet aan dat een vordering uit ongerechtvaardigde verrijking mogelijk is. Zo geeft art. 3:I2I lid 2 aan dat de bezitter niet te goeder trouw die kosten ten behoeve van het goed heeft gemaakt, recht heeft op vergoeding daarvan door de eigenaar op grond van 'het bepaalde omtrent ongerechtvaardigde verrijking' zodat art. 6:212 in beeld komt. Hetzelfde geldt voor art. 6:78 dat in geval van overmacht de teleurgestelde crediteur alsnog een recht op schadevergoeding geeft wanneer de schuldenaar in verband met de tekortkoming een voordeel geniet. In dat geval heeft de crediteur met toepassing van de regels betreffende ongerechtvaardigde verrijking recht op vergoeding van de schade tot ten hoogste het bedrag van dit voordeel. In de meeste gevallen ontbreekt een uitdrukkelijk antwoord en zal het antwoord op de vraag of de wet een legitimatie oplevert uit de strekking van de wettelijke regeling of bepaling moeten worden afgeleid. Het gaat hier dus om gevallen waarin de wet ertoe leidt dat de een verrijkt wordt ten koste van de ander, waarin de wet dus aanleiding geeft voor een vermogensverschuiving van de een naar de ander. Centraal staat vervolgens de vraag of met toepassing van art. 6:2I2 een compensatie voor deze verschuiving in de vorm van betaling van een geldsom moet plaatsvinden: ${ }^{889}$

'De vraag is dus telkens deze of, indien de wet ertoe leidt dat de ene persoon ten koste van een andere wordt verrijkt, uit haar strekking moet worden afgeleid dat ook het hierin gelegen financiële voordeel door de verrijkte mag worden behouden, of dat het redelijk is dat hij dit door betaling van een schadevergoeding aan de verarmde persoon moet afstaan.'

Het komt hier aan op het meergenoemde aftasten van de wet.

22. Welke argumenten spelen mee? Dat aftasten van, inpassen in en vaststellen van de wet of het wettelijk systeem is geen sinecure. Onderzocht moet worden of de betrokken wettelijke regeling de strekking heeft om een bepaalde verrijking te sanctioneren of niet. ${ }^{89 \circ}$ Het zal echter, ook na bestudering van haar parlementaire geschiedenis, niet steeds evident zijn wat de strekking van de betrokken wettelijke regeling is. In zo'n geval komt het dan veelal neer op een afweging van belangen van betrokkenen, hetgeen wat anders is dan een enkel gevoels- of billijkheidsoordeel. ${ }^{89 \mathrm{r}}$ Het stelsel 'van passen en aansluiten' leidt al snel tot het werken met aan de wet ontleende analogieën, maar wanneer deze onvoldoende houvast bieden moet men op zoek naar andere argumenten. Wissink noemt in dit verband traditie, buitenlandse

889 Asser-Hartkamp/Sieburgh 6-IV, nr. 466, p. 402.

890 Vriesendorp 2012, nr. 316.

89I Eindverslag I, Parl.Gesch. Boek 6, p. 836 en Wissink 2002, nr. 53. 
oplossingen, opportuniteit. ${ }^{892}$ Een ander, lastig, gegeven heeft te maken met de rechtsontwikkeling. De in het systeem gemaakte keuzes zijn niet onveranderlijk. In dit verband wordt veelal gewezen op het, in het licht van de arresten Quint/Te Poel en Vermobo/Van Rijswijk ${ }^{893}$ relevante, voorbeeld van de positie van de huurder die na beëindiging van het huurcontract aanspraak wenst te maken op vergoeding vanwege door hem aangebrachte verbeteringen. ${ }^{894}$ Waar voor het oude huurrecht nog werd beslist dat de huurder inmiddels vanwege zijn wegnemingsrecht alleen onder bijzondere omstandigheden de eigenaar/verhuurder op basis van ongerechtvaardigde verrijking kon aanspreken, ${ }^{895}$ krijgt deze vraag inmiddels vanwege de in art. 7:2I6 lid 3 neergelegde verrijkingsactie een ander accent. Dat klinkt door in het arrest Dupomex/De Haas-Duijvelaar c.s. ${ }^{896}$ Tot het wettelijk systeem behoren ook de redelijkheid en billijkheid zodat bij de vraag of art. 6:212 in een bepaald geval toepassing verdient ook hierop gebaseerde argumenten een rol kunnen spelen. ${ }^{897}$ Daarbij zou gedacht kunnen worden aan laakbaarheid van het gedrag van de verrijkte mede in het licht van de door Vranken ${ }^{898}$ centraal gestelde unclean hands-gedachte: hij signaleert in de rechtspraak een relatief soepele toepassing van art. 6:2I2 in gevallen waarin het handelen van verrijkte niet (geheel) zuiver is. ${ }^{899}$ Hoewel de toepassing van art. 6:212 geen louter billijkheidsoordeel moet zijn, ${ }^{900}$ houdt een systematische argumentatie ook rekening met art. 6:2 jo. 3:12 (redelijkheid en billijkheid): ${ }^{\text {90 }}$

'Die bepalingen vormen een wezenlijk onderdeel van het vermogensrechtelijk systeem. De redelijkheid en billijkheid verrijken dit systeem, omdat zij toelaten andere bepalingen aan te vullen, te corrigeren en verder te ontwikkelen. Waarom zou bij een toepassing van art. 6:212 welke zich oriënteert op het vermogensrechtelijk systeem, dit aan het systeem inherente element buiten beschouwing moeten of mogen worden gelaten?'

23. Aanvullende redelijkheidstoets Is eenmaal aan alle vereisten voldaan, dan geeft art. 6:212 in principe, binnen de marges van het dubbele plafond, ${ }^{902}$ recht op (volledige) vergoeding. Art. 6:2I2 laat echter ruimte voor de conclusie dat er weliswaar aan alle vereisten is voldaan doch toch geen (volledige) vergoeding plaatsvindt omdat zij niet redelijk zou zijn. Daarbij wordt nadrukkelijk gedacht aan het geval dat de verrijking buiten toedoen van verrijkte is ontstaan en hem als het ware wordt

892 Wissink 2002, nr. 53 .

893 HR 30 januari I959, NJ I959, 548 (DJV) en HR 29 januari I993, NJ I994, I72 (PvS).

894 Vranken I998, p. I502 en Wissink 2002, nr. 53.

895 HR I7 september I993, NJ I993, 740 (Reimes/Condstandse q.q.) en HR 20 september 2002, NJ 2004, 458 (JH) (Caribbean Bistros/Club Caraibeen NV).

896 HR 25 juni 2004, NJ 2005, 338. Zie over het arrest ook E.J.H. Schrage, 'Huurovereenkomst en verrijkingsrecht', Vermogensrechtelijke annotaties 2004, p. 68 e.v. en Schrage 2009, nr. I35 en I57.

897 Wissink 2002, nr. 53 .

898 Vranken I998, p. I497 e.v. Zie hierna 43.

899 Vgl. Wissink 2002, nr. 56.

900 Wissink 2002, nr. 53.

90I Wissink 2002, nr. 58, p. 69.

902 Hiervoor nr. I8. 
opgedrongen, zoals bijvoorbeeld bij verbetering van een zaak door een bezitter niet te goeder trouw of bij behartiging van eens anders belang zij het zonder redelijke grond (ongewenste bemoeizucht). Neem het voorbeeld van de schilder die het verveloze huis van een afwezige van een verflaag voorziet: dan is er een verrijking, verarming, causaal verband en bovendien ontbreekt een rechtvaardiging, maar moet de eigenaar de schilder werkelijk een vergoeding betalen?903 De wetgever heeft daarom bepaald dat vergoeding plaatsvindt 'voor zover dat redelijk is'. Deze tekst geeft de rechter de bevoegdheid alle omstandigheden in aanmerking te nemen en in verband daarmee de vordering geheel of gedeeltelijk af te wijzen.904 Deze tournure biedt bovendien de ruimte om de wijze waarop de schade vergoed wordt te beperken tot een bepaalde vorm. Gedacht kan worden aan het geval dat de verrijking bestaat in een bepaald goed. Het kan dan zijn dat toewijzing van schadevergoeding in geld niet redelijk is, maar een verplichting tot overdracht van dat goed aan de verarmde wel. In dit verband kan art. 6:I03 dat deel uitmaakt van afdeling 6.I.Io en de grondslag biedt voor schadevergoeding in een andere vorm dan geld uitkomst bieden..$^{905}$ Daarmee stuiten we al op de verhouding tot afdeling 6.I.Io. $\mathrm{Zij}$ is in die zin lastig dat 'voor zover dat redelijk is' een zo vage en ruime beperking is dat zij de bepalingen van afdeling 6.I.Io al snel overlapt. In dit verband wordt daarom vanuit wetssystematisch oogpunt wel bepleit de aanvullende toets van art. 6:212 te beperken tot typische aan de ongerechtvaardigde verrijking gerelateerde aspecten (voorkomen van opgedrongen prestaties bijvoorbeeld) en verder (bijvoorbeeld waar het gaat om vragen met betrekking tot de omvang van de vergoeding) aansluiting te zoeken bij afdeling 6.I.Io. ${ }^{906}$

24. Ontstaan, beperking en verval De verplichting tot vergoeding ontstaat zodra de verrijkte ten koste van de ander is verrijkt. Op de omvang van dat moment zal de vordering meestal dan ook zijn gebaseerd..$^{907}$ Zoals eerder aangegeven ${ }^{908}$ is dit ontstaansmoment ook bepalend voor de aanvang van de lange verjaringstermijn van 20 jaar uit art. 3:310 lid I. Hoewel de hoogte van de schadevergoeding wordt bepaald naar de situatie ten tijde van de verrijking, kan de omvang van de verrijking in de loop van de tijd veranderen. Verminderingen van de verrijking komen in principe voor risico van de verrijkte. De schade van de verarmde wordt gefixeerd naar het ogenblik van de verrijking en eventuele (waarde)verminderingen gaan hem niet aan. Omdat dit uitgangspunt echter niet altijd tot billijke resultaten zou leiden, is er in art. 6:2I2 de mogelijkheid opgenomen de vergoeding aan te passen. ${ }^{909}$ Zo wordt rekening gehouden met een latere vermindering van de verrijking als gevolg van een

903 Asser-Hartkamp/Sieburgh 6-IV, nr. 480. Zie nog HR 30 september 2005, NJ 2007, I54 (JBMV) (Koker/Cornelius) dat in nr. 53 centraal staat: in r.o. 3.6.3 in de opsomming onder $d$ komt het voorkomen van een opgedrongen verrijking aan de orde.

904 TM, Parl.Gesch. Boek 6, p. 83I

905 Zie ook HR 24 februari 20I2, NJ 2012, I43 (Post en Kleijweg/Kleijweg e.a.).

906 Zo Vriesendorp 20I2, nr. 322 en Asser-Hartkamp/Sieburgh 6-IV, nr. 48I.

907 TM, Parl.Gesch. Boek 6, p. 83I.

908 Nr. I7.

909 Asser-Hartkamp/Sieburgh 6-IV, nr. 482 en Vriesendorp 20I2, nr. 32I. 
omstandigheid die de verrijkte niet kan worden toegerekend (art. 6:2I2 lid 2). In zo'n geval wordt de verarming slechts vergoed tot het beloop van de verminderde verrijking. Denk bijvoorbeeld aan het geval dat een zaak door natrekking eigendom is geworden van de verrijkte en daarna buiten zijn schuld door een natuurramp of door een derde wordt beschadigd of zelfs tenietgaat. In dat geval blijft de verrijking buiten beschouwing voor zover zij door deze gebeurtenis is verminderd. ${ }^{\text {I’o }}$ Bovendien is er in sommige gevallen een beperking van de vergoeding zelfs in gevallen waarin de vermindering van de verrijking wel aan de verrijkte had kunnen worden toegerekend, zij het dat deze heeft plaatsgevonden in een periode waarin hij redelijkerwijze geen rekening hoefde te houden met een verplichting tot schadevergoeding (art. 6:212 lid 3). ${ }^{\text {II }}$ Hier zit achter dat de verrijkte in zo'n periode met de goederen is omgegaan op een manier die past bij het beeld dat het om zijn eigen spullen gaat: wanneer hij had geweten dat hij de (waarde van de) spullen voor een ander moest beheren, was hij voorzichtiger geweest. In een dergelijk geval wordt de waardevermindering niet aan de verrijkte toegerekend in het kader van de bepaling van de schadevergoeding die aan de verarmde moet worden betaald. De vermindering van de verrijking die krachtens art. 6:2I2 lid 3 buiten beschouwing blijft, omvat mede uitgaven die de verrijkte in die periode heeft gedaan en die hij achterwege zou hebben gelaten als de verrijking niet had plaatsgevonden. Het wordt niet redelijk geacht een ruimer uitgavenpatroon dat is aangepast aan de door de verrijking verbeterde vermogenspositie voor rekening van de verrijkte te laten komen indien en voor zover deze met een schadevergoedingsverplichting geen rekening behoefde te houden..$^{92}$

25. Geen achtergestelde positie Inmiddels hebben we zicht gekregen op de voorwaarden voor vergoeding, op de vergoedingsomvang en op het karakter van de eventuele verbintenis ex art. 6:212 (schadevergoeding, geen ongedaanmaking). Het wordt nu tijd de draad weer op te pakken en ons te richten op de vragen en problemen waartoe de introductie van een algemene verrijkingsactie in art. 6:212 aanleiding geeft. Een in dit verband nogal relevante vraag is hoe de verrijkingsactie van art. 6:2I2 zich verhoudt tot andere acties. Waar de vordering in andere rechtstelsels wel een subsidiair karakter heeft, gaat de toelichting daarvan niet uit. ${ }^{913} \mathrm{Zij}$ laat dus de mogelijkheid open voor een aanspraak op basis van ongerechtvaardigde verrijking ook in gevallen waarin een zodanige aanspraak op een andere rechtsgrond kan worden gebaseerd. Daarmee wordt voor het Nederlandse recht bewust afstand genomen van dat van Italië dat het subsidiariteitsvereiste in de wet heeft vastgelegd

9I0 Asser-Hartkamp/Sieburgh 6-IV, nr. 482.

9II Zie overigens ook het hierna in nr. 27 behandelde HR 29 januari 1993, NJ 1994, I72 (PvS) (Vermobo/Van Rijswijk). Aangesproken door Vermobo stelt Van Rijswijk senior in reactie op de ongerechtvaardigde verrijkingsvordering dat hij de varkensstal van zijn zoon heeft overgenomen en daartoe in totaal 93 ooo gulden heeft voldaan, zodat hij helemaal niet verrijkt is. Na verwijzing staat centraal de vraag of senior de betalingen heeft gedaan in de periode waarin hij redelijkerwijze nog geen rekening met de verplichting tot schadevergoeding rekening hoefde te houden.

912 Vriesendorp 20I2, nr. 32I en Asser-Hartkamp/Sieburgh 6-IV, nr. 482.

913 TM, Parl.Gesch. Boek 6, p. 830 (mede gelet op aldaar opgenomen voetnoot 3 ). 
en van het recht van Frankrijk ${ }^{914}$ en België welke landen een vergelijkbaar in de rechtspraak ontwikkeld leerstuk kennen. ${ }^{915}$ Voor het Nederlandse recht geldt dus dat de verrijkingsactie niet op voorhand al een achtergestelde positie heeft. Dat heeft de Hoge Raad in enkele beslissingen ook uitdrukkelijk bevestigd. Het gaat daarbij in de eerste plaats om Setz/Brunings. Nadat Brunings een stuk grond heeft gekocht van Condico voor 80.000 dollar, raakt hij nadat hij pas de helft van de termijnen heeft betaald in betalingsmoeilijkheden. Condico verkoopt de grond vervolgens aan Setz voor 47.000 dollar. Brunings spreekt daarop Setz aan op grond van ongerechtvaardigde verrijking. In het arrest, dat hierna uitvoerig aan de orde komt, ${ }^{916}$ valt het volgende te lezen: ${ }^{17}$

'3.4.2 (...) De enkele omstandigheid dat Brunings een vordering tot vergoeding van zijn schade tegen Condico zou kunnen richten staat echter, zoals ook het onderdeel tot uitgangspunt neemt, niet in de weg aan de gehoudenheid van Setz tot vergoeding van de schade die Brunings mocht hebben geleden doordat Setz ten koste van hem is verrijkt. Op dit een en ander stuit het onderdeel geheel af.'

Dat de ene partij al beschikt over een vordering op haar contractuele wederpartij staat dus niet in de weg aan een verrijkingsactie jegens een derde. In dezelfde lijn blijkt in een later arrest het enkele feit dat de verarmde al een andere vordering op de verrijkte heeft (in casu uit wanprestatie) niet in de weg te staan aan een verrijkingsactie jegens dezelfde persoon. ${ }^{918}$ De verrijkingsactie is dus niet op voorhand op achterstand gezet ten opzichte van andere grondslagen voor vergoeding.

26. Verarming of toch niet? Tegen deze achtergrond springen de beschouwingen van mijn naaste Maastrichtse collega Van Maanen in het oog. Hij bekommert zich om het voorkomen van een te ruim toepassingsgebied voor art. 6:212, juist omdat hij bang is voor doorkruising van hetgeen in het kader van andere leerstukken (zoals bijvoorbeeld dat van de onrechtmatige daad) tot ontwikkeling is gekomen. Hij stelt in dit verband weliswaar geen subsidiariteitseis, maar komt wel op een vergelijkbaar resultaat uit doordat hij een specifieke invulling geeft aan de verarmingsvraag. Kort en goed gaat Van Maanen ervan uit dat de getroffene niet verarmd is wanneer hij al over een andere (reële) vordering bijvoorbeeld op grond van wanprestatie beschikt. ${ }^{919}$

9I4 Zie nog G.E. van Maanen, 'Subsidiarity of the action for unjustified enrichment. French Law and Dutch Law: different solutions for the same problem', European Review of Private Law 2006, p. 409 e.v.

9I5 Zie ook Schrage 2009, nr. I5I e.v. Overigens heeft Gerdes 2006, p. 4-5 laten zien dat aanvankelijk Meijers zelf wel degelijk voorstander was van een subsidiariteitsvereiste. Het driemanschap achtte dat later niet nodig of juist in verhoudingen waarbij enkel twee partijen betrokken zijn, doch ook voor meerpartijenverhoudingen heeft men uiteindelijk besloten dat het beter zou zijn niets in de wet zelf op te nemen.

9 I6 Nr. 37.

917 HR 27 juni I997, NJ I997, 7 I9 (JH).

9I8 Zie HR 20 september 2002, NJ 2004, 458 (JH) (Caribbean Bistros/Club Caraibeen NV) en de noot van Hijma onder 9.

9I9 Van Maanen 200I, p. 46. 
Deze vordering maakt dan deel uit van zijn vermogen, zodat van verarming of schade per saldo geen sprake (meer) is. Daarbij maakt het voor hem overigens niet uit of het om een twee- of meerpartijenverhouding gaat. In het geval van het arrest Setz/Brunings, dat hem een doorn in het oog is, zou Van Maanen Brunings dan ook een vordering ex art. 6:2I2 op Setz willen ontzeggen, juist omdat Brunings al over een wanprestatievordering jegens Condico beschikt: deze vordering behoort tot zijn vermogen en voorkomt dat er bij hem van verarming sprake is. Hoewel het strikt genomen om een andere techniek gaat, wordt in deze visie wel degelijk een vergelijkbaar resultaat bereikt als bij het stellen van het subsidiariteitsvereiste. In de kern komt men in dit soort gevallen niet aan een verrijkingsactie toe, omdat er al een andere weg openstaat. Zij spoort daarom niet goed met het wettelijk stelsel en gaat bovendien uit van een ander schadebegrip dan we elders plegen te hanteren. ${ }^{920} \mathrm{Ik}$ ben daarom geneigd juist wel het wettelijk spoor te volgen: de verrijkingsactie is dus niet op voorhand op achterstand gezet ten opzichte van andere grondslagen voor vergoeding. Dan zijn we er echter nog niet. Sterker nog, juist hierdoor komen we voor nieuwe vragen te staan.

27. Ook vader en zoon schrijven geschiedenis Gegeven immers dat de verrijkingsactie niet op voorhand op achterstand is gesteld, kan zij in principe samenlopen met andere vorderingen. Naar gangbare inzichten is het antwoord op de vraag of eventuele mogelijke vorderingen naast elkaar kunnen bestaan, overgelaten aan de normale samenloopregels. Of de verrijkingsactie in concreto ook succesvol is, is daarmee niet gezegd. Dat is immers afhankelijk, zoals eerder gesteld, ${ }^{221}$ van een beoordeling van het wettelijk systeem: sanctioneert dat de verrijking of niet? Naar Nederlands recht is het bijvoorbeeld mogelijk een vordering te baseren op art. 6:2I2 ook al is tevens aan de voorwaarden van art. 6:I62 voldaan. De samenloopregels verzetten zich daar niet tegen. Een mooi voorbeeld daarvan biedt het arrest Vermobo/Van Rijswijk $k^{922}$ in een sterk op Quint/Te Poel lijkende casus. Aannemer Vermobo bouwt in opdracht van Van Rijswijk junior een varkensstal. De opdrachtgever blijkt vervolgens niet in staat om de aanneemsom te voldoen waarna de aannemer er achter komt dat de grond eigendom is van Van Rijswijk senior, zodat deze ook weer door natrekking eigenaar is geworden van de stal. In deze zaak spreekt Vermobo senior aan en brengt daarbij het gehele privaatrechtelijke arsenaal in stelling. Zo spreekt de aannemer Van Rijswijk senior aan op contractuele basis (afgewezen), maar ook op basis van onrechtmatige daad en ongerechtvaardigde verrijking. De beide laatste grondslagen worden, (iets te) kort gezegd, ${ }^{923}$ met succes in stelling gebracht. Hetgeen senior wist omtrent de financiële positie van zijn zoon had hem in deze situatie

920 Zo eerder al Wissink 2002, nr. 28 en 29 die onder meer de vraag stelt of in de visie van Van Maanen in een casus A-B-C de vordering ex art. 6:I62 jegens B niet zou moeten vervallen vanwege de vordering die A ex art. 6:2I2 heeft op C. Dat zeggen we toch ook niet? Waarom zou dat omgekeerd wel gelden? Kennelijk omdat er bij Van Maanen toch een subsidiariteitsgedachte op de achtergrond speelt.

92I Hiervoor nr. 9 en $2 \mathrm{I}$.

922 HR 29 januari I993, NJ 1994, 172 (PvS).

923 Na verwijzing volgt nog een verder onderzoek van deze twee grondslagen. 
aanleiding moeten geven zich de belangen van de aannemer aan te trekken, bijvoorbeeld door hem te waarschuwen.

28. Samenloop De vraag of de getroffene ook nog een vordering kan baseren op art. 6:2I2 terwijl zij reeds op andere grondslag aanspraak op vergoeding kan maken, wordt dus beheerst door de gewone samenloopregels die, zoals bekend is, in principe uitgaan van cumulatie zodat de verarmde beide (of zelfs méér dan twee) wegen kan bewandelen. ${ }^{924}$ Slechts bij uitzondering is sprake van alternativiteit of zelfs van exclusiviteit van een bepaalde regeling. Of een dergelijke uitzondering zich voordoet, dient door uitleg van de betrokken regeling te worden bepaald. Indien ongedaanmaking of schadevergoeding dus tevens door een andere regeling wordt beheerst, zal de vraag of een vordering ook op ongerechtvaardigde verrijking kan worden gebaseerd, moeten worden beantwoord aan de hand van de strekking van die andere regeling. In dit verband geeft de toelichting het voorbeeld dat na verjaring van de rechtsvordering tot vernietiging van een rechtshandeling niet alsnog een vordering op basis van ongerechtvaardigde verrijking mogelijk is. ${ }^{925}$

29. Méér dan een kwestie van samenloop? Daarmee is al enig licht geworpen op de verhouding van de verrijkingsvordering tot andere vorderingen. Voorop staat dat de verrijkingsactie geen achtergestelde actie is. Vervolgens komen de gewone samenloopregels in beeld die in principe toestaan dat een vordering op meerdere rechtsgronden tegelijk kan worden gebaseerd en die slechts bij uitzondering iets anders (alternativiteit of exclusiviteit) inhouden. En dan is er nog een derde vraag die opnieuw de verhouding tot andere grondslagen betreft, maar die minder eenvoudig te beantwoorden is: de vraag wanneer de afbakening van een andere rechtsgrond meebrengt dat een verrijking die met een op die andere rechtsgrond gebaseerde vordering niet aangepakt kan worden daardoor ook niet ongerechtvaardigd is, omdat zij blijkbaar door de wetgever na afweging van de over en weer bestaande belangen zonder bezwaar is geacht. ${ }^{226}$ Anders gezegd: verzet het feit dat een andere weg tot een nul op het rekest leidt, zich ook tegen een afwijzen van de verrijkingsactie? Een algemene regel is hier niet te geven. De toelichting geeft als voorbeeld van een geval waarin de verrijkingsactie juist wel succes kan opleveren het geval van behartiging van andermans belang zonder dat aan alle vereisten van zaakwaarneming is voldaan. Volgens de toelichting, die daarbij aansluiting zoekt bij de traditie en andere rechtstelsels, is dan een vordering uit ongerechtvaardigde verrijking niet uitgesloten. ${ }^{927}$ Daar komt voor de toelichting nog bij dat dit resultaat voor de hand ligt,

924 Asser-Hartkamp/Sieburgh 6-IV, nr. 475 e.v. en Vriesendorp 20I2, nr. 324.

925 TM, Parl.Gesch. Boek 6, p. 830. De passage roept wel vragen op. Dat na verjaring van de rechtsvordering tot vernietiging van een rechtshandeling niet alsnog een vordering op basis van ongerechtvaardigde verrijking mogelijk is, wil strikt genomen nog niet zeggen dat voordien, voordat de vernietigingsactie is verjaard dus, evenmin een ongerechtvaardigde verrijkingsactie mogelijk was. Ook bij Asser-Hartkamp/Sieburgh 6-IV, nr. 476 klinkt twijfel door.

926 MvA II, Parl.Gesch. Boek 6, p. 833. Zie ook Asser-Hartkamp/Sieburgh 6-IV, nr. 476 en Wissink 2002, nr. 2 I.

927 MvA II, Parl.Gesch. Boek 6, p. 833-834. 
omdat de aansprakelijkheid van art. 6:200 in beginsel verder gaat dan die ex art. 6:2I2 welke niet alleen is beperkt tot de verrijking maar ook nog ruimte laat voor verdere beperking op grond van de redelijkheid. Dat suggereert dat waar het meerdere niet (meer) kan, het mindere eventueel nog wel mogelijk is. Tegelijkertijd wordt gewezen op de elders in de parlementaire geschiedenis aan de orde gestelde verhouding tussen afdeling 6.4.2 (onverschuldigde betaling) en art. 6:212. ${ }^{22}$ Daarbij is ook weer de stelling betrokken dat art. 6:212 een wenselijke aanvulling biedt in gevallen waarin op afdeling 6.4.2 geen vordering kan worden gebaseerd. In dit verband wordt onder meer gedacht aan het geval dat iemand een ander onverschuldigd een goed heeft gegeven. Wanneer de crediteur genot derft dat aan de ander ten goede is gekomen, kan ter zake van dat genot eventueel een vergoeding plaatsvinden op basis van art. 6:212.929

30. De ene vraag is de andere niet De belangrijke vraag naar de verhouding tot andere vorderingen en grondslagen levert dus het beeld op dat er veel ruimte is voor de verrijkingsactie. Er geldt immers ten eerste geen subsidiariteitsvereiste, volgens de normale samenloopregels kan ten tweede al snel een actie uit ongerechtvaardigde verrijking worden ingesteld hoewel ook andere grondslagen beschikbaar zijn en dat een afwijzend antwoord in het kader van een andere grondslag zonder meer betekent dat de verrijkingsactie ook moet worden afgewezen, kan, ten derde, niet in zijn algemeenheid worden gezegd. Overigens blijkt bij de toepassing en uitwerking dat bepaalde vragen dicht tegen elkaar aan liggen. Zo kan men zich de vraag stellen hoe de verhouding is tussen het subsidiariteitsvereiste en het ontbreken van een oorzaak voor de verrijking. Beide zijn een begrenzingstechniek althans zijn als zodanig te gebruiken. Beide vereisen bovendien een beoordeling van (een deel van) het wettelijk systeem, zij het dat ieder dat met een eigen invalshoek doet. Waar de vraag naar (het ontbreken van) een oorzaak voor de verrijking het noodzakelijk maakt het wettelijk systeem af te tasten op zoek naar een legitimatie voor de verrijking bij gebreke waarvan er reden voor vergoeding ex art. 6:2I2 is, gaat het bij de subsidiariteitskwestie om een heel andere, nogal specifieke, vraag: staat het gegeven dat de verarmde ook al een andere vordering op de verrijkte of een derde heeft aan vergoeding op basis van art. 6:212 in de weg? Op die laatste vraag luidt het antwoord naar Nederlands recht duidelijk ontkennend.

\section{Art. 6:212: onbegrensd en onbemind?}

3I. Het grotere geheel Hoewel cumulatie uitgangspunt is bij samenloop, is de vraag naar de werkelijke, praktische, betekenis van een algemene verrijkingsactie daarmee niet beantwoord. Juist omdat er in veel gevallen al een vordering op een of meer andere grondslagen mogelijk is, zal art. 6:2I2 in veel gevallen onbenut

928 MvA II, Parl.Gesch. Boek 6, p. 834 waar wordt verwezen naar p. 803 en 807 .

929 TM, Parl.Gesch. Boek 6, p. 803. 
blijven, ${ }^{930}$ zeker wanneer men bedenkt dat, zoals in het voorgaande ook al aan bod is gekomen, ${ }^{931}$ art. 6:212 beperkingen kent die men bij andere acties niet tegenkomt. Ter relativering lijkt het daarom goed enige aandacht te besteden aan het grotere geheel: het stelsel van bronnen van verbintenissen dat het BW 1992 kenmerkt en waarvan art. 6:212 deel uitmaakt. In het arrest Quint-Te Poel liet de Hoge Raad ruimte voor een niet uitdrukkelijk in de wet geregelde vordering wanneer zij tenminste 'in het stelsel van de wet past en aansluit bij de wèl in de wet geregelde gevallen'. ${ }^{932}$ Deze bekende 'opening' in het systeem der bronnen van verbintenissen - verbintenissen behoeven niet per definitie een uitdrukkelijke wettelijke grondslag maar deze kan men ook 'tussen de wettelijke regels lezen'- ligt ook in art. 6:I besloten:

'Verbintenissen kunnen slechts ontstaan, indien dit uit de wet voortvloeit.'

In Boek 6 vindt men vervolgens regelingen van de belangrijkste bronnen van verbintenissen: overeenkomst (titel 6.5), onrechtmatige daad (titel 6.3) en daartussenin titel 6.4 dat ziet op verbintenissen uit andere bron dan onrechtmatige daad of overeenkomst. Deze titel valt uiteen in drie afdelingen die betrekking hebben op respectievelijk zaakwaarneming, onverschuldigde betaling en ongerechtvaardigde verrijking. De laatste afdeling bestaat enkel uit art. 6:2I2, waarbij men, zoals eerder al is aangegeven, ${ }^{933}$ niet uit het oog dient te verliezen dat het BW op diverse plaatsen specifieke bepalingen kent die een actie ter zake van ongerechtvaardigde verrijking inhouden. ${ }^{934}$ Voor art. 6:212 is, gegeven dat de behoefte aan toepassing mede afhankelijk is van de alternatieven die het systeem biedt, in het bijzonder van belang dat ons recht in afdeling 6.4.2 (onverschuldigde betaling) en afdeling 6.5.5 (ongedaanmaking na ontbinding wegens wanprestatie) twee uitgewerkte regelingen ter zake van de ongedaanmaking van reeds verrichte prestaties kent. Daar komt nog bij dat ook het in titel 6.3 gesitueerde aansprakelijkheidsrecht zeer veel ruimte biedt. 935 Zo kan dat bijvoorbeeld uitkomst bieden in een situatie van dubbele verkoop of andere situaties waarbij een derde betrokken is bij (en die bevoordeeld of benadeeld wordt door) een contract tussen twee andere partijen. In dit verband kan ook weer aan Vermobo/Van Rijswijk worden gedacht: Van Rijswijk senior heeft (mogelijk) onrechtmatig gehandeld jegens Vermobo door zich, hoewel hij de financiële positie van zijn zoon kende, de belangen van Vermobo onvoldoende aan te trekken. ${ }^{36}$

930 Wissink 2002, nr. 6 e.v. Zie ook Asser-Hartkamp/Sieburgh 6-IV, nr. 476.

93I Nr. I8 en 23.

932 HR 30 januari 1959, NJ I959, 548 (DJV) Quint/Te Poel.

933 Nr. 8.

934 Zie bijvoorbeeld de al eerder genoemde art. 3:I2I lid 2 (recht op vergoeding van kosten jegens de rechthebbende voor de bezitter niet te goeder trouw) en 6:78 (recht op schadevergoeding in geval van overmacht). En dan zijn er uiteraard nog andere bepalingen binnen en buiten het BW die in wezen ongerechtvaardigde verrijking beogen te voorkomen. Zie bijvoorbeeld art. 7:962 (subrogatie van de schadeverzekeraar).

935 Wissink 2002, nr. 6.

936 HR 29 januari 1993, NJ I994, I72 (PvS). Hiervoor nr. 27. 
32. Succesfactoren Het gaat echter niet alleen om de alternatieven binnen het systeem. Ook andere factoren bepalen de werkelijke behoefte en daarmee ook het werkelijke succes van een algemene verrijkingsactie. Zo mag worden aangenomen dat een 'negatieve' invloed uitgaat van de bestaande onduidelijkheid over de vraag of in een concreet geval aan de toepassingsvoorwaarden van art. 6:212 is voldaan: het gemis aan scherpte bij de toepassing van art. 6:212 zal er soms toe leiden dat van een vordering ex art. 6:212 wordt afgezien althans dat daarvan geen serieus werk wordt gemaakt. ${ }^{937}$ Ook het vergoedingsniveau, de omvang van de vergoeding die langs de weg van art. 6:2I2 te realiseren is, speelt een rol. Het al aangestipte dubbele plafond en ook de bevoegdheid van de rechter de vergoeding mede op basis van de omstandigheden te bepalen ('voor zover dat redelijk is') maken dat het aantrekkelijker kan zijn een andere vordering die wel steeds strekt tot volledige vergoeding van de werkelijk geleden schade te benutten..$^{93^{8}}$ Uiteindelijk is de vraag of de verrijkingsvordering kan worden ingesteld vooral van belang indien de verrijkte niet reeds op basis van een andere grondslag kan worden aangesproken. ${ }^{939}$ Daarbij valt te denken aan het geval dat een derde een schuld betaalt zonder 'redelijke grond' of in de veronderstelling dat hij zijn eigen schuld voldoet. In dat geval kan art. 6:198 (zaakwaarneming) geen uitkomst bieden omdat aan de daarin gestelde voorwaarden niet is voldaan. Een tweede categorie van gevallen betreft die waarin andere grondslagen niet tot vergoeding van de (gehele) schade van de benadeelde strekken. Te denken valt hier aan het geval dat iemand onverschuldigd een zaak levert, deze weliswaar kan terugvorderen op basis van art. 6:203 maar op die grondslag geen vergoeding kan krijgen voor het gebruik dat de ander enige tijd van de zaak heeft gehad. Een dergelijke vergoeding zou wel op art. 6:212 kunnen worden gebaseerd. De derde categorie is meteen problematisch: er is juist wel een andere, veelal contractuele, grondslag, maar er is tevens sprake van een insolventieprobleem. Denk aan Vermobo/Van Rijswijk en andere gevallen waarin werkzaamheden worden verricht op basis van een contract, de voordelen daarvan bij een derde uitkomen en de opdrachtgever niet in staat blijkt te betalen. Op zoek naar een wel solvabele debiteur komt inderdaad een ander, de derde, in beeld die ex art. 6:212 wordt aangesproken. Mede hieraan heeft de verrijkingsactie haar niet alleen maar goede naam te danken..$^{90}$ Het bezwaar is dat hier het insolventierisico wordt afgewenteld op een derde, terwijl het gaat om het risico van insolventie van een persoon die door zijn wederpartij is uitgekozen, terwijl deze haar crediteurspositie zelf niet heeft versterkt bijvoorbeeld door zekerheid te verlangen.

937 Dit is in de kern ook de inzet van het preadvies van Joke Baeck: onduidelijkheid over de toepassingsvoorwaarden maakt dat de actie minder snel zal worden toegepast dan wellicht aangewezen is.

938 Asser-Hartkamp/Sieburgh 6-IV, nr. 475. Zie hiervoor nr. I8 en 23.

939 Asser-Hartkamp/Sieburgh 6-IV, nr. 476.

940 Zie bijvoorbeeld W.J. Zwalve, 'Boekbespreking', WPNR 670I (2007), p. 21 2 en eerder al Brandsma I994, 270-27I. 
33. Tussenbalans Het is zeer wel mogelijk grote delen van het vermogensrecht als verrijkingsrecht te zien. Zinvol is dat in de regel echter niet. ${ }^{941}$ Bovendien bepalen in veel gevallen die in theorie tot denken in termen van ongerechtvaardigde verrijking aanleiding zouden kunnen geven, andere, meer specifieke, rechtsfiguren in de praktijk al de afwikkeling. ${ }^{942}$ Het is dan dus niet nodig om art. 6:2I2 toe te passen.

34. Onbegrensde mogelijkheden Hoezeer deze relativering ook op haar plaats is, feit blijft dat art. 6:2I2 een nogal ruim toepassingsbereik heeft. Dat een beroep op deze bepaling niet nodig is, dat er niet werkelijk behoefte aan is in het licht van andere vorderingen die de wet geeft, wil niet zeggen dat een beroep op art. 6:2I2 niet mogelijk is. Hier wreekt zich inderdaad dat ons verrijkingsrecht wars is van abstracte, het toepassingsbereik beperkende, regels. We hebben nu juist gezien dat wij, in de terminologie van Wissink, ${ }^{943}$ geen 'metaregels' kennen. Het subsidiariteitsvereiste kennen we niet, net zo min als een regel die zich verzet tegen toepassing op gevallen van indirecte verrijking. Neem het eerder genoemde geval van een aannemer die onder eigendomsvoorbehoud geleverd krijgt, het geleverde verwerkt bij de bouw van een pand ten behoeve van een derde die door natrekking eigenaar wordt. ${ }^{944}$ Wanneer de aannemer zijn leverancier niet betaalt, rijst de vraag of de derde niet ex art. 6:2I2 kan worden aangesproken door de leverancier. Naar Nederlands recht staat in zulke gevallen niet aan een vordering op de derde in de weg dat de leverancier al over een vordering op de aannemer beschikt. Ook anderszins is de vordering van de leverancier op de derde niet uitgesloten: art. 6:212 leent zich dus voor toepassing op indirecte verrijking. Hooguit geeft ons recht aanleiding tot vragen van afstemming tussen de diverse mogelijke grondslagen, zoals hiervoor al is aangegeven. ${ }^{945}$

35. Een omstreden rechtsfiguur Het ontbreken van dergelijke abstracte regels maakt dat de algemene verrijkingsactie door velen onbemind is. Het is niet voor niets een omstreden rechtsfiguur. Juist omdat het toepassingsbereik niet werkelijk is afgegrensd, vraagt (een deel van) de doctrine aandacht voor de bezwaren van deze actie. In dit verband wordt bijvoorbeeld gewezen op het feit dat de vordering onbepaald en ongrijpbaar is, vreest men pure billijkheidsrechtspraak en is er nadrukkelijk ook de vrees voor overlap met en doorkruising van andere rechtsfiguren en leerstukken. Dat laatste kan dan weer leiden tot het 'inlezen' of anderszins in het kader van art.

94I Wissink 2002, nr 7. Zie ook Janssen 2009, p. I57.

942 Wissink 2002, nr. 9.

943 Wissink 2002, p. I3 e.v.

944 Hiervoor nr. 3.

945 Nr. 28 en 29. 
6:2I2 'binnenhalen' van voorwaarden of beperkingen die bij andere vorderingen of grondslagen worden gesteld..$^{946} \mathrm{Wissink}$ verwoordt het goed: ${ }^{947}$

'Een al te ruimhartige toepassing van het verrijkingsrecht is niet per definitie wenselijk. Zo zou men, ten eerste, kunnen menen dat een te royale toepassing van verrijkingsrecht het vermogensrechtelijk systeem zou overwoekeren. Bestaande indelingen en gebruikelijke routes naar een bepaald resultaat hebben hun nut en moeten in principe worden gehandhaafd. Dit geeft voedingsbodem aan richtlijnen als 'vermogensverschuivingen in contractuele verhoudingen worden in principe op basis van het contract beoordeeld' of 'na vernietiging van een overeenkomst wordt de rechtsverhouding via de onverschuldigde betaling afgewikkeld'. Het vermogensrechtelijk systeem zou wellicht verstoord worden als in die gevallen met een verrijkingsvordering wordt gewerkt. Of dit risico reëel is, kan thans in het midden blijven. Wel kan alvast worden vastgesteld, dat dit punt niet zonder belang is. Het systeem is geen speeltje voor wetenschappers, maar een instrument om de inzichtelijkheid, voorspelbaarheid en hanteerbaarheid van het recht te bevorderen alsmede een gelijke behandeling van gelijke gevallen.'

Het ruime toepassingbereik speelt ons parten. Onbegrensd maakt onbemind. Dat blijkt zeker bij de rechtspraak in de eerste jaren na invoering van het BW 1992.

\section{Hype rond de eeuwwisseling}

36. Rode draad Het Nederlandse debat is op scherp gezet door de rechtspraak van de Hoge Raad in de eerste jaren na inwerkingtreding van het BW I992. Diverse arresten hebben kritiek uitgelokt, niet alleen in annotaties maar ook in bredere beschouwingen..$^{94^{8}}$ De rode draad is dat de Hoge Raad te veel ruimte geeft aan art. 6:2I2 en te weinig oog heeft voor andere vorderingen die binnen het systeem al bestaan. Het gaat daarbij niet alleen om de vraag of er in deze gevallen wel behoefte is aan art. 6:2I2, het gaat tevens, zo blijkt ook uit het zojuist gegeven citaat, om de vraag of die andere vorderingen en de in dat kader ontwikkelde regels niet worden doorkruist door toepassing van art. 6:212 en in uiterste instantie vreest men toewijzing van schadevergoeding enkel op grond van billijkheid.

946 Denk bijvoorbeeld aan het binnenhalen van de eis van verwijt of toerekenbaarheid of onzorgvuldigheid van bepaald gedrag naar het voorbeeld van art. 6:I62. Zie in dit verband J.W.M.K. Meijer, Ongerechtvaardigde verrijking, diss. Rotterdam, Sdu Uitgevers, Den Haag 2007 en de kritiek daarop in Asser-Hartkamp/Sieburgh 6-IV, nr. 466 en van E.H.J. Schrage, 'Ongerechtvaardigde verrijking. Een systematische analyse van het begrip ongerechtvaardigdheid, toegepast op kostenverhaal bij bodemsanering', Maandblad voor Vermogensrecht 2009, p. I9 e.v.

947 Wissink 2002, nr. 8.

948 Zie onder meer H.C.F. Schoordijk, 'Een vordering uit ongerechtvaardigde verrijking wegens het profiteren door apotheker van intrekking vergunning apotheekhoudend arts', NTBR I996, p. 247 e.v., H.C.F. Schoordijk, 'Indirecte verrijking, vertegenwoordiging, onrechtmatige daad en Pauliana', WPNR 6247 (I996), p. 86r e.v., Schoordijk 1997, Nieskens-Isphording I998, Van Maanen 200I, Zwalve i997. 
37. Dubbele verkoop in de West Hoewel bijvoorbeeld ook de arresten Vermobo/Van Rijswijk en Van der Tuuk/Batelaan stevig onder vuur zijn genomen, ${ }^{949}$ is het vooral het arrest Setz/Brunings dat de gemoederen bezig heeft gehouden. ${ }^{95^{\circ}}$ Ik herhaal nog maar eens kort de feiten: Brunings heeft een stuk grond gekocht van Condico voor 80.000 dollar, maar raakt nadat hij de helft van de termijnen heeft betaald in betalingsmoeilijkheden. Condico verkoopt de grond vervolgens aan Setz voor 47.00o dollar. Brunings spreekt daarop Setz aan op grond van ongerechtvaardigde verrijking: tweede koper Setz zou een bijzonder voordelige koopprijs hebben genoten wegens aftrek van de reeds door eerste koper Brunings verrichte betalingen. Een voor de hand liggende grondslag zou zijn dat de tweede koper onrechtmatig handelt jegens de eerste koper, doch hier was en is vaste rechtspraak dat de enkele wetenschap van de tweede koper omtrent een eerder met een derde gesloten overeenkomst niet voldoende is om de tweede koper aansprakelijk te doen zijn jegens de eerste koper. ${ }^{951}$ Daarvoor zijn bijzondere omstandigheden nodig. ${ }^{952}$ Tegen deze achtergrond is het interessant te bekijken wat de lotgevallen van de verrijkingsvordering zijn. Het hof wees haar, kort gezegd, toe: Brunings zou zijn verarmd omdat hij zijn recht op levering van het perceel niet meer aan een derde kan verkopen. De daarmee verband houdende verrijking van Setz ten bedrage van 33.000 dollar is ongerechtvaardigd nu niet is gebleken dat daarvoor een redelijke grond aanwezig is. In cassatie richt Setz zijn pijlen op het oordeel dat Brunings is verarmd nu hem - door de verkoop en overdracht door Condico aan Setz - de mogelijkheid is ontnomen om zijn recht op levering van het perceel voor dat bedrag aan een derde te verkopen. 's Hofs oordeel dat de verrijking van Setz ongerechtvaardigd is nu niet is gebleken dat daarvoor een redelijke grond aanwezig is, wordt in cassatie echter ongemoeid gelaten. In de kern betoogt Setz in cassatie dat Brunings door de overdracht van het perceel door Condico aan hem geen schade heeft geleden. Brunings heeft immers, aldus het middelonderdeel, ook na de overdracht van het perceel aan Setz, nog altijd een - tegen Condico uit te oefenen - recht tot levering. De Hoge Raad wijst er echter op dat hier door de overdracht van het perceel door Condico aan Setz sprake is van onmogelijkheid van nakoming door Condico van haar uit de overeenkomst met Brunings voortvloeiende verbintenis tot overdracht van de eigendom van het perceel aan Brunings of een derde op wie het aan Brunings toekomende recht op levering mocht zijn overgegaan. Brunings rest daarom ter zake van zijn overeenkomst met Condico nog slechts een op wanprestatie gegronde vordering jegens Condico tot vergoeding van zijn schade:

'De enkele omstandigheid dat Brunings een vordering tot vergoeding van zijn schade tegen Condico zou kunnen richten staat echter, zoals ook het onderdeel tot uitgangspunt neemt, niet in de weg aan de gehoudenheid van Setz tot vergoeding van de schade

949 HR 29 januari I993, NJ I994, I72 (PvS) en HR I5 maart I996, NJ I997, 3 (E.H.J. Schrage).

950 HR 27 juni 1997, NJ 1997, 7I9 (JH).

95I Op deze achtergrond wijst Zwalve i997, p. 585-586 nadrukkelijk.

952 Die in casu wellicht aan de orde zijn. Zie Schoordijk I997, p. I75I. 
die Brunings mocht hebben geleden doordat Setz ten koste van hem is verrijkt. Op dit een en ander stuit het onderdeel geheel af.'

Hier lezen we dus dat art. 6:2I2 geen subsidiaire actie is. ${ }^{953}$ Dan komt's hofs oordeel dat de verarming van Brunings verband houdt met de verrijking van Setz in beeld. In cassatie wordt betoogd dat het verband tussen de verrijking van Setz en de verarming van Brunings onvoldoende is om een vordering wegens ongerechtvaardigde verrijking van Brunings tegen Setz te aanvaarden. De Hoge Raad geeft hier echter nul op het rekest:

'De gedachtengang die het Hof tot zijn bestreden oordeel heeft geleid, moet klaarblijkelijk aldus worden begrepen dat, in aanmerking genomen dat Setz het perceel, dat US\$ 80 ooo waard was, uitsluitend voor niet veel meer dan de helft van de waarde heeft kunnen kopen als gevolg van de omstandigheid dat Brunings als koper reeds US\$ 37 935,74 aan Condico had betaald, tussen de verrijking van Setz en de verarming van Brunings een verband bestaat dat de conclusie wettigt dat de verrijking ten koste van Brunings is geschied. Aldus opgevat geeft het bestreden oordeel niet blijk van een onjuiste rechtsopvatting. (...)'

De consequentie is hier dus dat Brunings Setz inderdaad met succes ex art. 6:2I2 kan aanspreken. Hoe moeten wij dit nu waarderen?

38. Reserve en kritiek Vooropgesteld zij dat het een zaak is waarin de feiten mistig blijven, zodat enige reserve bij de waardering van het arrest gerechtvaardigd is. ${ }^{954}$ Het roept ook dan echter nogal wat vragen op. Zo is de consequentie dat Brunings de tweede koper Setz dus wel degelijk op grond van ongerechtvaardigde verrijking kan aanspreken, terwijl dat op grond van art. 6:I62, gelet op de rechtspraak met betrekking tot profiteren door een derde van wanprestatie, niet zonder meer mogelijk zou zijn. Het verbaast dan ook niet dat de vraag is gesteld of dit klopt en zo ja of dit dan eigenlijk niet zou betekenen dat de art. 6:I62-rechtspraak aan herziening toe is. ${ }^{955}$ In ieder geval is het eindresultaat dat Brunings nu twee debiteuren heeft: niet alleen kan hij Condico aanspreken uit wanprestatie, ook Setz is jegens hem aansprakelijk en wel ex art. 6:2I2. In dit verband springt ook het al aangeduide causaliteitsoordeel van de Hoge Raad in het oog: in cassatie wordt vergeefs betoogd dat er geen enkel

953 Hiervoor nr. 25.

954 Niet gek lijkt mij de suggestie van annotator Hijma die in de stukken proeft dat de insolvent geraakte Brunings, nadat hij in Setz een vervangster had gevonden, met haar over het 'overnemen' van zijn positie heeft gesproken, waarna Brunings (en/of Setz) bij verkoper Condico de indruk heeft gewekt dat men er wel zo ongeveer uit was en de gedane betalingen onderling zou rechttrekken. In feitelijke instanties heeft Brunings inderdaad primair gesteld dat hij met Setz een 'deal' had gesloten althans dat die aanstaande was. Hij kon dat echter niet bewijzen. Vervolgens kwam de subsidiaire grondslag, ongerechtvaardigde verrijking, in beeld.

955 Zwalve 1997 , p. 586. 
causaal verband tussen verrijking en verarming bestond. Zwalve zit juist wel op dit spoor: 956

'Stel, bijvoorbeeld, eens dat B niet C, maar verkoper A met vrucht had aangesproken. Had deze vervolgens een vordering tegen $\mathrm{C}$ kunnen instellen omdat $\mathrm{C}$ ten koste van hem is verrijkt? Het antwoord luidt, natuurlijk, ontkennend en wel omdat $C$ het stuk grond niet voor 80.000 wilde kopen. Duidelijker kan het ontbreken van een voldoende causaal verband tussen de "verarming" (zo men daarvan wil spreken) van de een en de "verrijking” van de ander niet worden toegelicht.'

Voor Zwalve is het arrest een bewijs van de wens van de Hoge Raad de vordering uit ongerechtvaardigde verrijking zo veel mogelijk ruimte te geven: de Hoge Raad heeft 'een nieuw speeltje' gevonden. Van Maanen richt zich vooral op het resultaat dat Brunings, hoewel hij reeds over een reële (wanprestatie)vordering op verkoper Condico beschikt, daar nu nog een tweede vordering bij krijgt met alle problemen van dien. ${ }^{957}$ Stel bijvoorbeeld dat Brunings na Setz met succes te hebben aangesproken, vervolgens Condico zou aanspreken tot terugbetaling van de reeds betaalde termijnen ex art. 6:27I (ongedaanmaking na ontbinding wegens wanprestatie). Dat zou weliswaar niet moeten kunnen, maar men heeft kunst- en vliegwerk nodig om dat te voorkomen. In dit verband stelt Hartkamp dat Condico een beroep op de beperkende werking van de redelijkheid en billijkheid zou moeten kunnen doen, juist om te voorkomen dat toewijzing tot ongerechtvaardigde verrijking van Brunings zou leiden. Hier heeft ongerechtvaardigde verrijking dus een afwerende functie: zij wordt als verweermiddel ingezet tegen een nakomings- of ongedaanmakingsvordering van een ander..$^{95^{8}}$ Van Maanen wil zich, zoals hij zegt, niet in deze bochten van Hartkamp wringen en neemt juist aan dat Brunings niet verarmd is, omdat hij reeds over een reële vordering op Condico beschikt. ${ }^{959}$ In deze visie op het verarmingsvereiste komt men aan de door Hartkamp beschreven problemen inderdaad niet toe. Hiervoor ${ }^{960}$ heb ik echter al aangegeven dat deze visie onder meer omdat zij feitelijk tot een achterstelling van de verrijkingsactie leidt niet algemeen gedeeld is en ook niet door mij wordt onderschreven. Wat daarvan verder zij, ook Schoordijk uit vergelijkbare forse kritiek op het arrest dat hij in de sleutel zet van een te pas en te onpas aangevoerd verrijkingsrecht; hij acht het arrest 'in een qua feiten schimmige drie-partijen-verhouding' weinig overtuigend uitgevallen. ${ }^{96 \mathrm{r}}$ Net als Zwalve stelt ook hij de vraag of Setz Condico nog zou kunnen aanspreken.

956 Zwalve I997, p. 586. Ook Nieskens-Isphording I998, p. Ior is juist op dit punt kritisch. Zij spreekt van een puur feitelijk verband (koper $C$ heeft het perceel voor een lage prijs kunnen kopen als gevolg van het feit dat koper A de helft had voldaan), maar wijst erop dat verarming en verrijking niet correleren, niet wederzijds afhankelijk zijn van elkaar. De beweerde verarming zou bestaan in het frustreren van het recht van koper A om zijn rechten op levering te cederen. Deze staat echter los van de verrijking van de tweede koper met de helft van de waarde van de grond, zij zou zich immers ook voordoen wanneer de tweede koper de volle waarde had moeten betalen.

957 Zie daarover Hartkamp 200I, p. 327 e.v.

958 Hierna nr. 45 .

959 Van Maanen 200I, p. I4-I5 en hiervoor al nr. 26.

960 Nr. 26.

96I Schoordijk I997, p. I754. 
Beiden zijn immers aansprakelijk jegens Brunings: Condico op grond van wanprestatie, Setz ex art. 6:2I2. Geheel onzinnig is het niet aan te nemen dat de draagplicht bij Condico ligt en Setz uit hoofde van zijn contract met Condico dan wel met een buiten-contractuele verrijkingsvordering Condico kan aanspreken, aldus Schoordijk. Uit de diverse genoemde beschouwingen blijkt in ieder geval dat een royale toepassing van art. 6:2I2 in gevallen van indirecte verrijking als hier aan de orde leidt tot allerlei vragen over de precieze verhouding tussen de betrokkenen: is in hun onderlinge verhouding een redelijk eindresultaat, een reële draagplicht gerealiseerd of niet? Daarbij is het dan nog een hele toer om te voorkomen dat toewijzing van een verrijkingsvordering bij verdere afwikkeling tussen de betrokkenen tot ongerechtvaardigde verrijking van een ander leidt. Dan moet, al dan niet onder het kleed van de beperkende werking van de redelijkheid en billijkheid, de ongerechtvaardigde verrijking als afweermiddel worden ingezet. Het is een hoge prijs die we betalen voor een arrest waarin ook de Hoge Raad, zo lijkt het althans, zijn best doet een billijke oplossing te vinden in een bijzonder geval: het kan toch niet zo zijn dat Setz er in dit geval met de buit vandoor gaat, terwijl Brunings achter het net vist?

39. Het hek is van de dam In dit verband is het van belang kennis te nemen van de kritiek van Nieskens-Isphording. Zij valt het arrest juist aan op het punt van de ongerechtvaardigdheid van de verrijking. Bij het laatste hecht zij veel waarde aan het contract tussen B (Condico) en C (Setz): ${ }^{96}$

'Een geldige overeenkomst tussen partijen is, als de ratio bij uitstek voor de vermogensverschuiving, daarvoor eveneens "redelijke grond" bij uitstek. Ook bij bevoordelingsintentie is dit niet anders.'

In haar benadering ontneemt men juist aan de verrijkingsactie het karakter van een billijkheidsactie die Nieskens-Isphording onder meer in Setz/Brunings meent aan te treffen: ${ }^{963}$

'Gekozen lijkt te worden voor een "billijkheidsactie" die het mogelijk maakt op (gevoelsmatig) redelijke gronden tot juridisch niet toetsbare resultaten te komen.'

In dezelfde sfeer ligt het al in de inleiding aangehaalde eindoordeel van Van Maanen die de ontwikkelingen in de rechtspraak in 200I graag een halt zou toeroepen en: ${ }^{964}$

'het hek moet weer op de dam...'

40. Steun van gezaghebbende zijde De verrijkingsrechtspraak van de Hoge Raad is echter niet alleen kritiek ten deel gevallen. Willen we een evenwichtig beeld geven van de ontwikkelingen dan is het ook van belang in te gaan op de uitvoerige

962 Nieskens-Isphording I998, p. I04 en daarvoor al op p. I03.

963 Nieskens-Isphording I998, p. Io9.

964 Van Maanen 200I, p. 5 I. 
beschouwingen van Vranken en Hartkamp die beiden juist steun hebben betuigd aan de wijze waarop de Hoge Raad art. 6:2I2 is tegemoet getreden..$^{95}$ Vranken bijt in 1998 het spits af: ${ }^{966}$

'De Hoge Raad heeft meteen hoog ingezet: geen zware, van rechts- of wetsgeschiedenis doordrenkte overwegingen over wanneer een vordering uit ongerechtvaardigde verrijking wel of niet toelaatbaar zou kunnen zijn, maar gewoon doen. Het ziet ernaar uit dat de Hoge Raad hiermee serieus werk maakt van de erkenning/codificatie van de vordering in het BW van 1992 en er een volwaardige plaats voor wil inruimen in het huidige arsenaal van mogelijke remedies.'

Weliswaar plaatst ook hij kanttekeningen bij het arrest Setz/Brunings, zeker waar het de motivering en de feitelijke grondslag betreft, doch hij hecht wel degelijk zijn zegel aan de overweging omtrent de subsidiariteitsvraag die de weg vrijmaakt voor een ruime samenloop van verrijkingsvorderingen met vorderingen uit onrechtmatige daad en wanprestatie. Hij beoordeelt deze ruime samenloop juist positief en zet zich daarbij af tegen geleerden als Nieskens-Isphording en Van Maanen, die de verrijkingsvordering enkel met grote terughoudendheid wensen te hanteren. Tegelijkertijd ziet ook Vranken een uitdaging in het voorkomen van pure billijkheidsrechtspraak. ${ }^{967}$ Vergelijkbaar positief is Hartkamp in zijn Amsterdamse oratie in 2001: ${ }^{968}$ ook hij signaleert dat de Hoge Raad ruim baan geeft aan het nieuwe art. 6:2I2. ${ }^{969}$ De kritiek in de doctrine zet Hartkamp in de sleutel van vrees voor een 'algemene billijkheidsactie' bij invoering waarvan 'vrijwel elke toepassing van het overige vermogensrecht aan correctie door de billlijkheid (zou) zijn onderworpen'.970 Deze kritiek verrast hem, omdat juist onder het oude recht soepelheid werd bepleit, overigens onder de begrijpelijke waarschuwing dat de verrijkingsactie moest worden ingepast in het stelsel van het bestaande recht om te voorkomen dat zij dat stelsel op ongerechtvaardigde wijze zou doorbreken. Hartkamp schaart zich vervolgens achter Vranken: niet alleen acht hij het juist dat de Hoge Raad serieus werk maakt van art. 6:2I2 en geen subsidiariteitsvereiste stelt, hij bestrijdt ook dat de verrijkingsvordering slechts met uiterste terughoudendheid zou mogen worden gehanteerd..$^{971}$

4I. Bijvangst Belangrijker dan hun verdediging van de rechtspraak van de Hoge Raad acht ik hun beider poging de functies van de verrijkingsactie in kaart te brengen. Een aardige 'bijvangst' van de doctrinaire discussie over de koers van de Hoge Raad is dan ook dat het denken juist over die functies verder is gezet: na Vranken en Hartkamp

965 Vranken I998 en Hartkamp 200I, p. 3II e.v.

966 Vranken 1998 , p. 1496.

967 Schoordijk 1997, p. I503.

968 Hartkamp 200I, p. 3II e.v.

969 Hartkamp 200I, p. 3II. Zie ook nog A.S. Hartkamp, De horizontale werking van het (primaire) recht van de Europese Unie en het Nederlandse vermogensrecht, preadvies voor de Vereniging voor de vergelijkende studie van het recht van België en Nederland, Boom Juridische uitgevers, Den Haag 20II, p. 334 .

970 Hartkamp 200I, p. 313.

97I Hartkamp 200I, p. 313-3I4. 
hebben ook W. Snijders en Wissink zich nadrukkelijk in het debat gemengd. Vranken onderscheidt, tegen de achtergrond van de door hem onderzochte rechtspraak in de periode 1992-I998, een viertal functies van de verrijkingsvordering:972

- een aanvullende;

- een beperkende;

- een correctie op onbehoorlijk gedrag (unclean hands); en

- een zingevende.

De aanvullende en de beperkende beschouwt Vranken als de klassieke functies van de verrijkingsvordering. Aanvullend werkt zij daar waar het niet goed mogelijk is om op een andere grondslag recht te doen. ${ }^{973}$ Hoewel in de parlementaire geschiedenis diverse voorbeelden van deze werking worden genoemd, spreekt Vranken van een lastige categorie gevallen omdat er weinig andere aanknopingspunten lijken te zijn dan de billijkheid. ${ }^{974}$ Corrigerend noemt Vranken de werking van de verrijkingsvordering bijvoorbeeld bij het bouwen op andermans grond. De gevolgen van de natrekkingsregel die meebrengt dat de eigenaar van de grond ook eigenaar wordt van het gebouwde kunnen dan onder voorwaarden met behulp van de verrijkingsactie worden aangepakt, gecorrigeerd dus. ${ }^{975}$ In dit verband kan aan Vermobo/Van Rijkswijk worden gedacht. ${ }^{976}$ Bijzondere aandacht schenkt Vranken aan een tweetal nieuwe functies. De nadruk ligt daarbij op het bieden van een sanctie in gevallen waarin het gedrag van diegene jegens wie de verrijkingsvordering wordt uitgeoefend niet (helemaal) zuiver is (unclean hands). Met de zingevende functie wordt gedoeld op gevallen waarin de verrijkingsvordering wordt gebruikt om wettelijke bepalingen een zinvolle betekenis te geven.

42. Zingeving In dit laatste verband pleegt het arrest Staat/Meijer te worden genoemd. ${ }^{977}$ In deze zaak betaalde de Ontvanger op een bankrekening van Meijer die door deze rechtsgeldig van betaling was uitgesloten in de zin van art. 6:II4 waarvan het eerste lid luidt:

972 Vranken 1998 , p. I496 e.v.

973 Als voorbeeld kan dan HR 28 juni 1996, NJ 1997, I02 (M-groep) dienen: de Ontvanger spreekt M-groep met succes aan uit onrechtmatige daad wegens het kopen van vennootschappen met het vooropgezette doel deze leeg te halen en vervolgens te verkopen zonder met de fiscus af te rekenen. Na verkoop bieden deze vennootschappen geen verhaal meer. Door vergoeding door de M-groep van de schade zijn de belastingschulden tenietgegaan en heeft, aldus Hoge Raad, M-groep een regresvordering op de belastingplichtige vennootschappen die zonodig op art. 6:212 gegrond kan worden.

974 Hij ziet dat bevestigd in het arrest HR I5 maart I996, NJ I997, 3 (E.H.J. Schrage) (Van der Tuuk Adriani/Batelaan) waarin het gaat om een claim van een huisarts wiens vergunning om een apotheek te houden werd ingetrokken ten gunste van een apotheker die zich in het gebied vestigde, zonder dat de huisarts van hem een vergoeding ontving.

975 Zie in dit verband ook F.H.J. Mijnssen, 'Goederenrechtelijke aspecten van ongerechtvaardigde verrijking', WPNR 6657 (2006), p. I74 e.v.

976 HR 29 januari $1993, \mathrm{NJ}$ 1994, I72 (PvS).

977 HR 28 februari I997, NJ I998, 2 I8 (HJS). Zie ook Schrage 2009, nr. II6 en II7. 
Bestaat in een land waar de betaling moet of mag geschieden ten name van de schuldeiser een rekening, bestemd voor girale betaling, dan kan de schuldenaar de verbintenis voldoen door het verschuldigde bedrag op die rekening te doen bijschrijven, tenzij de schuldeiser betaling op die rekening geldig heeft uitgesloten.

Wanneer er ondanks uitsluiting toch op een dergelijke rekening wordt betaald, rijst de vraag wat daarvan nu de consequentie moet zijn. In ieder geval heeft de crediteur altijd voordeel van de betaling: ofwel groeit het positieve saldo op de rekening, dan wel vermindert het negatieve. Wanneer dit reeds voldoende zou zijn voor de conclusie dat het geld aan de crediteur ten goede is gekomen, zou de uitsluitingsbevoegdheid van art. 6:II4 zinledig zijn. Tegelijkertijd zou het ook gek zijn wanneer de crediteur het op de uitgesloten rekening betaalde zou mogen behouden en vervolgens nog een tweede keer betaling zou mogen vorderen. In feite krijgt hij dan tweemaal betaald. Onder vigeur van het BW 1992 is daarom gekozen voor de oplossing dat een crediteur die betaling weigert zonder het betaalde terug te betalen, een vordering uit onverschuldigde betaling tegen zich moet laten gelden. ${ }^{978}$ Die vordering kan dan verrekend worden met de vordering om opnieuw te betalen. In deze zaak wordt duidelijk dat dit niet altijd werkt, in het bijzonder niet wanneer de crediteur niet kán terugstorten. Wordt dan toch verrekening toegelaten dan is art. 6:II4 nog altijd een dode letter. Waar A-G Hartkamp in deze zaak meende dat met behulp van de beperkende werking van de redelijkheid en billijkheid onrechtvaardigheden te vermijden zijn, ${ }^{979}$ kiest de Hoge Raad een andere weg: van onverschuldigde betaling is geen sprake, de betaling is wel degelijk verschuldigd maar administratief verkeerd uitgevoerd. De Hoge Raad neemt slechts een verplichting tot terugbetaling van het op de uitgesloten rekening gestorte bedrag aan indien de crediteur daarmee is verrijkt. Dat is het geval wanneer het geld te zijner beschikking is gekomen op dezelfde voet als bij betaling op een niet uitgesloten rekening. Vranken spreekt zijn waardering uit voor deze beslissing omdat zij leidt tot een invulling van art. 6:II4 die de risico's en de belangen van crediteur en debiteur evenwichtig verdeelt. Weliswaar zou met behulp van de beperkende werking van de redelijkheid en billijkheid ten dele hetzelfde kunnen worden bereikt - degene die op de uitgesloten rekening heeft betaald werpt degene die op grond van art. 6:II4 opnieuw betaling vordert tegen dat dit in de gegeven omstandigheden naar maatstaven van redelijkheid en billijkheid onaanvaardbaar is - , maar: ${ }^{80}$

'als de beperking nu juist gemotiveerd moet worden met een beroep op omstandigheden in de sfeer van ongerechtvaardigde verrijking, vind ik het scherper en meer voor de hand liggend het op die grondslag af te wikkelen.'

Vranken acht deze zingevende functie van de verrijkingsvordering nieuw en geslaagd, doch geeft tegelijkertijd aan dat het bereik ervan niet groot zal zijn omdat

978 Dat wordt afgeleid uit MvA II, Parl.Gesch. Boek 6, p. 46I.

979 Conclusie onder I4.

980 Vranken 1998 , p. I497. 
een vergelijkbaar geval niet gauw te bedenken of te construeren is. Belangrijker acht hij dat een aantal arresten in de sleutel van een sanctie op unclean hands kunnen worden gezet.

43. Vuile handen In dit verband noemt hij de arresten Reimes/Constandse, Vermobo/ Van Rijswijk, Setz/Brunings en Ontvanger/Hamm. ${ }^{98 \mathrm{I}}$ In de eerste zaak is Wout Goos BV failliet gegaan. Directeur Reimes hield ook 50\% van de aandelen. Een deel van de onroerende zaken die in de onderneming werden gebruikt, huurde de BV van Reimes in privé. Centraal staat een mede op ongerechtvaardigde verrijking gebaseerde actie van curator Constandse; Reimes is in privé verrijkt doordat de BV in de onroerende zaken heeft geïnvesteerd. Waar in het algemeen werd aangenomen, juist vanwege het wegnemingsrecht van de huurder (art. 7A:I603 (oud)), dat alleen onder bijzondere omstandigheden een verrijkingsactie zou kunnen slagen, komt deze uitzondering hier in beeld. Reimes had het wegnemingsrecht als directeur van huurster (Goos BV) kunnen uitoefenen, maar als verhuurder/eigenaar van het gehuurde had hij belang bij het tegenovergestelde. Het wegnemingsrecht werd niet gebruikt, waarna de BV (huurster) failliet ging. De curator kon Reimes hier met succes op basis van ongerechtvaardigde verrijking aanspreken..$^{82}$ Deze zaak zit volgens Vranken dicht tegen de beperkende werking van de redelijkheid en billijkheid aan (degene die willens en wetens een recht van een ander frustreert, kan niet aan de ander tegenwerpen dat hij het recht aan zich voorbij heeft laten gaan) maar waar dat een verdedigingswapen is, zocht de curator een aanvalswapen. Daartoe dienden meerdere grondslagen zich aan, waaronder de actie uit ongerechtvaardigde verrijking. Ook in Ontvanger/Hamm ${ }^{983}$ is de verbinding met de beperkende werking van de redelijkheid en billijkheid aan de orde en is opnieuw geen verdedigings- maar een aanvalswapen nodig. Centraal staat een betaling door de Ontvanger aan Wolfson Informatica BV die eigenlijk voor een andere firma was bedoeld. De betaling geschiedde na faillietverklaring van Wolfson en was een onmiskenbare vergissing. De curator die had kunnen weten dat het bedrag niet Wolfson aanging, weigerde echter terug te betalen. Hier vond de Ontvanger zijn aanvalswapen, om in het beeld van Vranken te blijven, in de ongerechtvaardigde verrijking die het gevolg zou zijn wanneer de boedelcrediteuren de baten van het onrechtmatig handelen van de curator q.q. zouden mogen behouden. Dat wapen had ook een onrechtmatige daad-actie van de curator q.q. kunnen zijn: ${ }^{984}$

98I HR I7 september I993, NJ I993, 740, HR 29 januari I993, NJ I994, I72 (PvS), HR 27 juni I997, NJ I997, 7I9 (JH) en HR 5 september I997, NJ I998, 437 (PvS)). In het meergenoemde arrest Vermobo/Van Rijswijk steunt het oordeel over de ongerechtvaardigde verrijking op precies dezelfde omstandigheden als het oordeel over de onrechtmatigheid. De Hoge Raad maakt geen verschil. Voor beide is, aldus Vranken, een toerekenbare onzorgvuldigheid vereist.

982 HR I7 september I993, NJ I993, 740.

983 HR 5 september I997, NJ I998, 437 (PvS).

984 Vranken 1998, p. I500. 
'maar omdat ook dán het verrijkingsaspect, het zich ten koste van anderen onrechtmatig bevoordelen, beslissend zal zijn, vind ik het scherper en meer voor de hand liggend het op die grondslag af te wikkelen.'

Waar Vranken toekomst ziet weggelegd voor de verrijkingsvordering als aanvallende pendant van de beperkende werking van de redelijkheid en billijkheid, brengt Wissink daartegen in dat deze aanvallende verschijningsvorm samenvalt met de aanvullende werking van de ongerechtvaardigde verrijking. ${ }^{985}$ Hij ziet dan ook, naar mijn idee terecht, geen aanleiding voor een zelfstandige betekenis van de 'unclean hands'-gedachte.

44. Aanvulling, beperking en uitleg Hartkamp komt in zijn Amsterdamse oratie tot een iets andere indeling en terminologie dan Vranken. Hij betoogt dat de verrijkingsactie dezelfde functies heeft als de redelijkheid en billijkheid van art. 6:2 en 6:248 waarbij zijn opvattingen over achtergrond en grondslag van de verrijkingsactie hem hebben geïnspireerd: ${ }^{86}$

- een aanvullende werking, die de aanvullende en beperkende functie van Vranken omvat;

- een beperkende werking, waarbij gedoeld wordt op het verweer dat toewijzen van een bepaalde vordering tot ongerechtvaardigde verrijking van de eiser zou leiden; en

- een functie bij uitleg van wetsbepalingen die min of meer samenvalt met de zingevende functie van Vranken.

Ook bij Hartkamp staat de aanvullende werking voorop. Op het eerste gezicht is daarbij verwarrend dat hij daar ook de beperkende (corrigerende) functie van Vranken onderbrengt, maar bij nader inzien heeft hij gelijk: de beperkende werking die Vranken bijvoorbeeld bij natrekking aanwijst, is in wezen een toepassing van de aanvullende functie van de verrijkingsvordering: omdat het niet mogelijk is om op andere grondslag recht te doen, wordt de verrijkingsactie aangewend. ${ }^{987}$ Hartkamp zit wel op een vergelijkbaar spoor als Vranken bij diens zingevende functie. ${ }^{988} \mathrm{Hij}$ ziet echter geen zelfstandige functie weggelegd voor de verrijkingsvordering bij unclean hands. ${ }^{989}$ Hij wijst er daarbij op dat in drie van de vier door Vranken genoemde gevallen unclean hands bij gedaagde niet vaststaat, zodat de veronderstelling dat de laakbaarheid van (het gedrag van) gedaagde een rol heeft gespeeld bij toewijzing van een verrijkingsactie op drijfzand is gebaseerd. ${ }^{99^{\circ}}$ Dat Hartkamp drie functies

985 Wissink 2002, nr. 55 .

986 Hartkamp 200I, p. 317 e.v.

987 Hartkamp 200I, p. 3I8. In vergelijkbare zin Wissink 2002, nr. 39 en 40.

988 Hartkamp 200I, p. 330. Zie ook Wissink 2002, nr. 48 en 49.

989 Snijders 200I, p. I7 en Wissink 2002, nr. 56 sluiten zich hierbij aan, doch Wissink ziet wel ruimte voor het meenemen van unclean hands/laakbaarheid van gedrag als gezichtspunt bij de beoordeling van de toewijsbaarheid van een verrijkingsvordering. Zie ook hiervoor nr. 22.

990 Hartkamp 200I, p. 330. 
(aanvullende, beperkende en een functie bij de uitleg van contracts- of wetsbepalingen) onderscheidt die precies samenvallen met de functies van de redelijkheid en billijkheid uit art. 6:2 en 6:248 is geen toeval. De ongerechtvaardigde verrijking is voor hem een concretisering van de redelijkheid en billijkheid. ${ }^{99}$

45. Verweermiddel Op dat spoor komt hij ook tot een beperkende werking van de verrijkingsvordering. In feite gaat het hier om een verweermiddel dat is gebaseerd op ongerechtvaardigde verrijking. Hiervoor is dit fenomeen bij de bespreking van Setz/ Brunings ${ }^{992}$ al kort aangestipt. ${ }^{993}$ Eerste koper Brunings krijgt zijn verrijkingsactie jegens tweede koper Setz toegewezen. Stel dat daarna de koopovereenkomst tussen hem en Condico wordt ontbonden wegens wanprestatie dan zou Brunings voor zover hij betaling van Setz heeft ontvangen niet ook nog restitutie ex art. 6:27I van het aan Condico betaalde moeten kunnen vorderen. Zou dat wel kunnen, dan zou Brunings juist ongerechtvaardigd worden verrijkt, dit keer ten koste van Condico. Op een vergelijkbare manier kunnen we naar Vermobo/Van Rijswijk kijken. ${ }^{994}$ Stel bijvoorbeeld dat aannemer Vermobo, wiens wederpartij Van Rijswijk junior niet in staat is de aanneemsom te voldoen, succes heeft met zijn zowel op art. 6:212 als op 6:I62 gebaseerde acties tegen Van Rijswijk senior. Dat zou Vermobo dan toch in de weg moeten zitten bij het vervolgens alsnog (proberen te) benutten van een nakomingsactie jegens Van Rijswijk junior? Een eventuele toewijzing jegens zoon Van Rijswijk zou Vermobo ongerechtvaardigd verrijken. Daarom moet de nakomingsvordering op die grond kunnen worden afgeweerd. Centraal staat hier steeds de (wenselijkheid van) afwijzing van een tweede vordering, een nakomings- of ongedaanmakingsvordering, om te voorkomen dat eiser tweemaal betaling ontvangt. Omdat hier naar heersende inzichten geen sprake is van hoofdelijke verbondenheid, laat voldoening van de ene vordering de andere strikt genomen onverlet. Daarom moet een ander middel worden ingezet. Hartkamp zoekt de oplossing hier in de beperkende werking van de redelijkheid en billijkheid die toepasselijk is omdat en in zoverre toewijzing van de actie tot ongerechtvaardigde verrijking zou leiden. In feite gaat het hier dus om een verweermiddel dat is gebaseerd op ongerechtvaardigde verrijking. ${ }^{955}$ Ook anderen zien de meerwaarde van deze functie juist bij indirecte verrijkingsacties ${ }^{996}$ waarbij overigens zij aangetekend dat zij deze niet steeds op de (beperkende) werking van de redelijkheid en billijkheid baseren. ${ }^{997}$ Hier komen de beschouwingen van W. Snijders in beeld.

99I Hartkamp 200I, p. 33I.

992 HR 27 juni I997, NJ I997, 719 (JH).

993 Nr. 38.

994 HR 29 januari 1993, NJ I994, I72 (PvS).

995 Hartkamp 200I, p. 328-329.

996 Het verweermiddel kan ook betekenis hebben in procedures waarin toewijzing van een ongedaanmakings- of schadevergoedingsactie (bijvoorbeeld wegens onterecht geïnde belastingen) tot verrijking zou leiden juist omdat eiser de lasten al heeft afgewenteld op anderen (afnemers bijvoorbeeld). Zie nog hierna nr. 58 .

997 Zie bijvoorbeeld Vriesendorp 20I2, nr. 328, Wissink 2002, nr. 47 en Snijders 200I, p. II. Van Maanen 200I, p. I4-I5 meent echter dat Hartkamp 'de zaak op zijn kop zet en zich in juridische bochten [moet] wringen om uit de problemen te komen die zijn veroorzaakt door deze onjuiste 
46. Systematische functie Hij heeft aandacht gevraagd voor de systematische functie van de verrijkingsactie. In deze benadering staat het systeem als argumentatiekader centraal. ${ }^{998}$ Ook Snijders verzet zich tegen loutere billijkheidsoordelen. ${ }^{999} \mathrm{Hij}$ ziet de ongerechtvaardigde verrijking juist als een geschikt instrument om het wettelijk stelsel uit te bouwen en te verfijnen. ${ }^{1000}$ Dat zou de meest wezenlijke functie van de actie zijn, zo leidt Snijders af uit de parlementaire geschiedenis. ${ }^{\text {10or }} \mathrm{Hij}$ maakt dat vervolgens concreet aan de hand van een voorbeeld: nadat hij het wettelijk systeem heeft geanalyseerd en daaruit heeft afgeleid dat rechtszekerheid en een vlot lopend betalingsverkeer hoge prioriteit hebben, ${ }^{1002}$ bespreekt hij een drietal arresten waarin ongerechtvaardigde verrijkingsvragen in het betalingsverkeer aan de orde zijn (Ontvanger/Hamm, Staat/Meijer en Standard/ING). ${ }^{1003}$ Ik ga deze analyse hier niet dunnetjes overdoen; waar het om gaat is dat hij voor alle drie de zaken tot de conclusie komt dat geen sprake is van zuivere billijkheidsoverwegingen, maar dat de beslissingen steeds zijn terug te voeren op het in de wetssystematiek verankerde belang van een vlot verlopend betalingsverkeer. ${ }^{1004} \mathrm{Hij}$ zet zich vervolgens af tegen Hartkamp die de nadruk legt op de billijkheid als algemene grondslag voor de verrijkingsvordering. Weliswaar is Snijders het met de uitwerking van Hartkamp vooral eens, hij komt derhalve niet tot werkelijke andere resultaten: ${ }^{\text {:005 }}$

'Wat me evenwel treft is dat men weinig opschiet een vage maatstaf als ongerechtvaardigde verrijking te willen verklaren of nader invulling te geven door te refereren aan een nog vagere maatstaf als de eisen van redelijkheid en billijkheid.'

Snijders legt juist de nadruk op het systeem van het vermogensrecht dat door de toelating van de verrijkingsvordering eigenlijk pas zijn uiteindelijke gedaante krijgt. ${ }^{\text {Ioo6 }}$ Voor bedoelde en onbedoelde overgangen van vermogensrechten van de een op de ander levert het wettelijk kader waarbinnen het circulatieproces in samenleving en economie zich voltrekt bijna altijd een afdoende rechtvaardiging op, maar van tijd tot tijd gaat het mis en is een middel nodig om een ongerechtvaardigde vermogensverschuiving ongedaan te maken. Andere figuren als wanprestatie, onrechtmatige daad en onverschuldigde betaling kunnen vaak de oplossing bieden maar zijn relatief botte instrumenten die tot volledige schadevergoeding of terugbeta-

toepassing van de actie uit art. 6:212 BW.' In de benadering van Van Maanen die door zijn visie op het verarmingsvereiste feitelijk een achtergestelde positie van art. 6:2I2 aanneemt, komen we aan het probleem van 'dubbel profiteren' niet toe. Zie hiervoor nr. 26. Tegen Van Maanen nog

A.F. Salomons, 'Verrijking, billijkheid en verdelende gerechtigheid', WPNR 6467 (200I), p. 994. 998 W. Snijders, Ongerechtvaardigde verrijking en het betalingsverkeer, Offerhaus-Kring, Kluwer, Deventer $20 I I$.

999 Snijders 200I, nr. I.

IO0o Snijders 200I, nr. 2.

IOoI Hij verwijst daarbij naar Parl.Gesch. Boek 6, p. 832-835.

I002 Snijders 200I, nr. 5 .

I003 HR 5 september I997, NJ I998, 437 (PVS), HR 28 februari I997, NJ I998, 2I8 en HR I februari 2002, $\mathrm{NJ} 2002,218(\mathrm{JH})$.

I004 Snijders 200I, nr 8, 9.

I005 Snijders 200I, nr. I2.

I006 Snijders 200I, nr. I3. 
ling verplichten. Juist zijn relatieve vaagheid, aldus nog steeds Snijders, maakt de ongerechtvaardigde verrijking een beter instrument om die taak te vervullen: $z \mathrm{ij}$ is flexibel genoeg om het zo te hanteren dat het systeem van het privaatrecht niet in gevaar komt, maar juist wordt verfijnd. Zo kan de figuur een redelijk evenwicht brengen tussen de diverse betrokken algemene en individuele belangen. De nadere regels die uit dit beleid resulteren, gaan op hun beurt weer van het stelsel deel uitmaken.

47. Hoe en wat De rechtspraak sinds 1992 heeft, zo is wel duidelijk geworden, tot een stevig debat over de koers van de Hoge Raad en over plaats en functie van art. 6:2I2 geleid. In zijn belangrijke analyse van dit debat in zijn preadvies voor de Vereniging voor Burgerlijk recht heeft Wissink getracht ordening aan te brengen door een tweetal typen taken of functies te onderscheiden: ${ }^{\text {:007 }}$

- taken die iets zeggen over wat we met ongerechtvaardigde verrijking kunnen doen: in dit verband kan aan aanvulling, beperking, zingeving worden gedacht; en

- taken die iets zeggen over hoe we met ongerechtvaardigde verrijking kunnen omgaan: in dat verband dient een ander type vraag zich aan (dient de verrijkingsvordering al dan niet terughoudend te worden toegepast, vormt zij een sluitstuk van het systeem en geen panacee voor zielige gevallen, welke argumenten kunnen een rol spelen?).

Gegeven dat de zingevende functie in betekenis beperkt is, ${ }^{1008}$ gaat het in de eerste categorie vandaag de dag vooral om de aanvullende en de beperkende functie. De aanvullende werking is klassiek: zij beoogt recht te doen wanneer een andere actie niet (goed) mogelijk is. Hier valt een parallel te trekken met de redelijkheid en billijkheid van art. 6:248 lid I, zij het dat het object van aanvulling hier niet een overeenkomst is maar het vermogensrechtelijk systeem. ${ }^{\text {.oog }}$ Deze functie - een middel om recht te doen in gevallen waarin een actie op een andere grondslag niet (goed) mogelijk is - hangt in technisch opzicht samen met de vraag naar de ongerechtvaardigdheid van de verrijking omdat ook zij aftasten van het systeem vergt. ${ }^{\text {roro }}$ Hoewel deze functie algemeen is aanvaard, is haar toepassing niet eenvoudig. Waarom is een verrijking ongerechtvaardigd? Wat zijn de relevante argumenten? ${ }^{\text {ror }} \mathrm{Ik}$ kom daarop hierna nog terug. ${ }^{\text {or2 } 2}$ De betekenis van de beperkende functie of werking ligt vooral bij een afwerende functie in meerpartijenverhoudingen. Daarbij valt in het spoor van Hartkamp en Wissink een tweetal typen gevallen te onderscheiden:

I007 Wissink 200I, nr. 33 .

Ioo8 Hiervoor nr. 42

Ioog Wissink 2002, nr. 35 en 36.

Ioro Wissink 2002, nr. 37. Zie ook hiervoor nr. I4 en 2 I.

IOII Wissink 2002, nr. 38 . Hiervoor nr. 22.

IoI 2 Nr. 48 e.v. 
- het voorkomen van dubbel profiteren in gevallen die lijken op situaties van hoofdelijkheid maar dat technisch gezien niet zijn;

- gevallen waarin een verschuiving van het insolventierisico aan de orde is.

Het eerste type gevallen is hiervoor aan de hand van Setz/Brunings en Vermobo/Van Rijswijk al aan de orde geweest. Met een op ongerechtvaardigde verrijking gebaseerd verweermiddel kan voorkomen worden dat Brunings respectievelijk Vermobo tweemaal 'vangen': eerst met een verrijkingsactie jegens Setz en Van Rijkswijk senior, daarna met een ongedaanmakingsvordering op Condico en een nakomingsvordering jegens Van Rijswijk junior. Bij de tweede categorie, waarin een verschuiving van het insolventierisico aan de orde is, betoogt Wissink dat Hartkamp te snel beslist waar toch een nadere belangenafweging noodzakelijk zou zijn. ${ }^{\text {Ior3 }}$ Neem het voorbeeld waarin A een zaak verkoopt aan B die haar weer doorverkoopt aan C. B draagt A op de zaak rechtstreeks aan $\mathrm{C}$ te leveren. Na levering door A aan $\mathrm{C}$ blijken beide overeenkomsten nietig wegens overschrijding van een maximumprijsvoorschrift. A kan alleen $\mathrm{C}$ aanspreken uit onverschuldigde betaling. Maar, aldus Hartkamp, die vordering dient geen resultaat te hebben indien $\mathrm{C}$ vooruit heeft betaald aan $\mathrm{B}$ en $\mathrm{B}$ gefailleerd is. Ook hier zou $\mathrm{C}$ zich dan moeten kunnen verweren tegen de actie van A met een exceptie uit ongerechtvaardigde verrijking. Wissink wijst op het verschil met de vorige categorie: hier gaat het niet om dubbel profiteren door A, maar om het voorkomen dat $\mathrm{C}$ tweemaal lijdt (immers zijn zaak én zijn geld kwijt is). Hier zou de afwerende functie dan de ratio hebben dat het onwenselijk is dat het insolventierisico van $\mathrm{B}$ van $\mathrm{A}$ op $\mathrm{C}$ is overgegaan. Waarom zou dat risico echter bij A moeten liggen, waar C ervoor gekozen heeft vooruit te betalen? Wissink acht hier een nadere belangenafweging noodzakelijk waarbij eventueel ook aan de orde kan komen of $\mathrm{C}$ er bij B op heeft aangedrongen A rechtstreeks aan $\mathrm{C}$ te laten leveren. Wat hiervan verder ook zij, de beperkende/afwerende functie ${ }^{1014}$ vervult een serieuze rol indien men, zoals ten onzent het geval is, aanvaardt dat in meerpartijenverhoudingen ruimte bestaat voor niet-subsidiaire indirecte verrijkingsacties; aanvaardt men deze niet, dan bestaat aan deze functie geen behoefte. ${ }^{\text {ors }}$ Daarmee is in ieder geval duidelijk wat we met art. 6:212 kunnen doen, waartoe deze bepaling ons in staat stelt. $\mathrm{Nu}$ de vraag hoe we daarmee omgaan: ruimhartig of juist terughoudend, welke argumenten spelen een rol?

48. Systematiek en rechtspolitiek Aangekomen bij deze vraag gaat Wissink naar mijn idee terecht in op de systematische functie van Snijders. Deze doet hem herinneren aan de discussie in de parlementaire geschiedenis over nut en noodzaak van het opnemen van een algemene actie. ${ }^{\text {orl }}$ De nadruk op systematische argumen-

IOI3 Wissink 2002, $\mathrm{nr} 44$.

IoI4 Overigens is het niet nodig deze functie te stoelen op redelijkheid en billijkheid, zo betoogt Wissink, 2002, nr. 47 onder verwijzing naar een vergelijkbare toepassing in Europeesrechtelijk verband waar het Hof van Jusitie toestaat dat een vordering uit onverschuldigde betaling wordt afgeweerd met (een beroep op) ongerechtvaardigde verrijking.

IOI5 Wissink 2002, nr. 46. Zie in dit verband ook Van Maanen 200 I en Janssen 2009.

I0I6 Wissink 2002, nr. 5I. Hiervoor nr. 7. 
ten in deze parlementaire geschiedenis brengt niet noodzakelijkerwijs mee dat de bepaling terughoudend zou moeten worden toegepast. ${ }^{\text {I017 }}$ Dat het bij toepassing van art. 6:2I2 aankomt op 'inpassen en aansluiten' betekent niet dat restrictieve toepassing vooropstaat. Dat is ook niet wat Snijders bedoelt met de systematische functie; het gaat hier niet om een rechtspolitieke keuze voor een beperkte rol van de verrijkingsactie. Om te bezien of de vordering toewijsbaar is, moet men echter wel het wettelijk stelsel ten einde denken. Anders gezegd: het systeem biedt een argumentatiekader bij de beoordeling van de toewijsbaarheid van de verrijkingsvordering. Wissink situeert deze systematische functie daarom dan ook bij de vraag hoe we met ongerechtvaardigde verrijking moeten omgaan. Daarbij is uiteraard niet de centrale vraag 'systematiek of loutere billijkheid?'. ${ }^{\text {ror } 8}$ 'Ongerechtvaardigd' is ook niet hetzelfde als 'onbillijk'. Ongemotiveerde gevoelsoordelen waren te voorkomen. Waar het op aankomt, is systematisch argumenteren met oog voor stelsel en strekking van de wet. Deze aanpak biedt vervolgens ruimte voor allerlei typen argumenten, niet alleen aan de wet ontleende analogieën, maar bijvoorbeeld ook op traditie, rechtsvergelijking of redelijkheid en billijkheid gebaseerde argumenten. ${ }^{\text {1org }}$

49. Per saldo De kritiek op rechtspraak van de Hoge Raad en het in het verlengde daarvan gevoerde debat over plaats en functie(s) van de verrijkingsactie heeft naar mijn indruk opgeleverd dat in ieder geval aanvulling, beperking en zingeving tamelijk algemeen als functie worden onderkend. ${ }^{1020}$ Omdat de zingevingsfunctie een praktisch beperkte betekenis heeft, komt het vooral aan op de andere twee functies. De beperkende functie of werking hangt sterk samen met de ruimte die er is voor gevallen van indirecte verrijking. Omdat die naar huidig recht niet stelselmatig van toepassing van art. 6:2I2 zijn uitgesloten, ontstaat er behoefte aan een verweermiddel dat bijvoorbeeld 'dubbel profiteren' moet voorkomen. Dit verweermiddel kan worden gebaseerd op ongerechtvaardigde verrijking. De aanvullende, beperkende en zingevende functie sluit goed aan bij vergelijkbare functies van de redelijkheid en billijkheid, maar kan men ook aannemen wanneer men, anders dan Hartkamp bijvoorbeeld, (redelijkheid en) billijkheid niet als grondslag voor ongerechtvaardigde verrijking ziet. Met het aanwijzen van deze functies is, in het onderscheid van Wissink, enkel nog maar aangegeven wat we met de verrijkingsactie kunnen. Vervolgens rijst een tweede vraag: hoe gaan we met de verrijkingsactie om? Passen we haar bijvoorbeeld restrictief toe of niet? Dat is een vraag die samenhangt met de vraag welke argumenten een rol spelen bij de beoordeling. Hier heeft de systematische functie van Snijders meerwaarde. Zij maakt ten eerste duidelijk dat het niet aankomt op het geven van zuivere billijkheidsoordelen, maar op het doordenken en, zo nodig, verfijnen van het systeem. Ten tweede geeft zij richting bij de vraag welke argumenten een rol kunnen spelen: behalve tekst, stelsel en geschiedenis van de wet, gaat het dan om in de wet nagestreefde of gewaarborgde belangen (denk aan

IOI7 Wissink 2002, nr. 52.

IOI8 Wissink 2002, nr 53.

Iorg Hiervoor nr. 22.

I020 Zie Hartkamp 200I, Snijders 200I, Wissink 2002, Vriesendorp 2012. 
het door Snijders als illustratie gebruikte belang van een vlot lopend betalingsverkeer), maar men kan ook denken aan op redelijkheid en billijkheid terug te voeren argumenten. ${ }^{1021}$

50. Rust aan het front? Naar mijn inschatting heeft het debat over plaats en functie(s) van de verrijkingsvordering een bepaalde helderheid en daarmee rust gebracht, hetgeen niet betekent dat elke auteur dezelfde accenten legt of dat iedere rechterlijke beslissing enkel met vreugde wordt begroet. Algemeen aanvaard lijkt inmiddels dat de verrijkingsactie geen achtergestelde actie is. We kennen geen beperkingen op voorhand: het subsidiariteitsvereiste wordt niet gesteld en ook een beperking tot gevallen van directe verrijking kent ons recht niet. Gegeven de normale samenloopregels kan de verrijkingsactie dus makkelijk samenlopen met andere acties. Dat is veelal geen probleem, omdat er in veel gevallen geen behoefte aan de verrijkingsactie bestaat. In gevallen waarin die andere acties nul op het rekest geven, ligt dat anders. Dat betekent, zoals eerder al is aangegeven, niet dat de verrijkingsactie in die gevallen slaagt: bij de uiteindelijke boordeling moet dan uiteraard worden 'meegenomen' dat andere in het systeem gesitueerde acties tot een afwijzing aanleiding geven. ${ }^{\text {.022 }}$ Dat er een zekere rust aan het front is gekomen, heeft ook hiermee te maken dat de Hoge Raad na 2002 enkele arresten heeft gewezen waarin hij zich bepaalde kritiek lijkt te hebben aangetrokken. De rechtsoverwegingen in belangrijke arresten lijken uitvoeriger en inzichtelijker. En, belangrijker nog, in het bijzonder op het punt van de vraag of de verrijking is gerechtvaardigd door een in het geval betrokken overeenkomst lijkt de Hoge Raad ook zijn koers te hebben aangepast. Dat is in de recentere literatuur opgetekend, zij het niet met steeds dezelfde conclusies: waar de een dat met vreugde begroet, ziet de ander in de jongste arresten juist aanleiding voor te stellen alsnog het bereik van art. 6:2I2 in te perken door de gevallen van indirecte verrijking uit te sluiten. Het is de hoogste tijd dat we daarnaar gaan kijken. Waar staan we anno 2012 ?

\section{Waar staan we anno 20I2: beperking of groei?}

51. Kentering Deze vraag staat in de eerste plaats in het teken van de rechtspraak nu de Hoge Raad enkele interessante arresten heeft gewezen waarin de rol van een overeenkomst bij de legitimatievraag aan de orde is. Hier heeft de Hoge Raad zowel voor gevallen van directe als voor indirecte verrijking meer duidelijkheid gebracht, zozeer zelfs dat een criticus als Van Maanen meent dat de kou uit de lucht is. ${ }^{1023}$ Janssen grijpt deze rechtspraak echter aan om de gevallen van indirecte verrijking alsnog buiten art. 6:212 te laten. ${ }^{\text {I024 }}$ Opmerkelijk genoeg menen anderen juist dat

IO2I Voor Wissink, nr. $5^{8}$ hoeft de grondslag niet te worden betrokken bij de vraag welke argumenten een rol spelen. Zie ook nog W. Snijders 2008.

I022 Hiervoor nr. 28 en 29.

I023 Van Maanen 2006 en G.E. van Maanen, 'Ongerechtvaardigde verrijking. In balans na vijftig jaar', Vermogensrechtelijke annotaties 2006, p. 37 e.v.

I024 Janssen 2009. 
art. 6:212 met zijn toepassingsvoorwaarden ons in de weg zit: zolang schade en verarming vereist zijn, bestaat de mogelijkheid dat men een ongerechtvaardigd voordeel mag behouden. Waar staan we dus en waar gaat het heen?

52. De overeenkomst als legitimatie Laten we beginnen met de rechtspraak over de legitimerende werking van een overeenkomst. In principe is een verrijking die gebaseerd is op een geldige rechtshandeling tussen verarmde en verrijkte niet ongerechtvaardigd. Het feit dat de prestaties niet gelijkwaardig zijn, brengt daarin geen verandering. ${ }^{1025}$ Wie aan een ander een zaak schenkt of verkoopt tegen een prijs die ligt beneden de marktwaarde verarmt zichzelf en verrijkt zijn wederpartij doch deze verrijking is niet ongerechtvaardigd, omdat zij kennelijk door partijen is beoogd. Hetzelfde geldt voor het opzeggen van een voor de opzeggende partij voordelig contract of voor het kwijtschelden of verlagen van een schuld. ${ }^{1026}$ In het verlengde van het voorgaande ligt het voor de hand dat een vordering uit ongerechtvaardigde verrijking eventueel wel mogelijk is wanneer een verrijking is opgetreden die niet door partijen was beoogd. ${ }^{\mathrm{I} 27}$ In dit verband kan het arrest Lisman van Raay Stichting/ Sint Willibrordus Stichting als illustratie dienen. ${ }^{\mathrm{102} 8}$ Centraal staat de verkoop van een kerkgebouw. Na overdracht ontstaat, kort gezegd, een geschil over beelden die zich in het kerkgebouw bevonden en die door natrekking eigendom werden van de koper. Deze nagetrokken beelden waren echter niet in de koop begrepen, zodat de koper die met verkrijging van het gebouw ook de beelden had verkregen ongerechtvaardigd was verrijkt. ${ }^{1029}$ Een ander voorbeeld betreft de zaak ProAv Zuid-Holland/ AVA. ${ }^{103^{\circ}}$ ProAv en AVA hebben een eerder samenwerkingsverband ontbonden en hebben vervolgens een huurovereenkomst met betrekking tot een loods gesloten waarbij in de door ProAv te betalen huurprijs van $f 780.000$ per jaar een bedrag van $f_{514.000}$ per jaar is opgenomen, dat strekt tot vergoeding van de verliezen die aan de zijde van AVA in het kader van de eerdere samenwerking zijn geleden. Om te voorkomen dat een eventuele ontbinding wegens wanprestatie van de huurder ProAv ertoe zou

I025 Zo TM, Parl.Gesch. Boek 6, p. 829.

I026 Niet ondenkbaar is dat de verrijking het gevolg is van een gebrekkige totstandkoming van de rechtshandeling (dwaling, bedrog, bedreiging of misbruik van omstandigheden (art. 6:228 en 3:44)). In dat geval kan de benadeelde de rechtshandeling als zodanig aantasten waarna als gevolg van de terugwerkende kracht van vernietiging (art. 3:53 lid I) verbintenissen uit onverschuldigde betaling (afdeling 6.4.2) ontstaan. Langs die weg is dan herstel in de vorige toestand te realiseren. Onduidelijk is of in gevallen waarin een rechtshandeling vernietigbaar is in plaats daarvan een verrijkingsactie kan worden ingezet. Dat is in wezen een vraag van samenloop die nog niet duidelijk is beantwoord. Zie Asser-Hartkamp/Sieburgh 6-IV, nr. 465 en 476 . Hetgeen daarover in de parlementaire geschiedenis wordt opgemerkt, is niet sluitend. In TM, Parl.Gesch. Boek 6, p. 830 wordt gesuggereerd dat de regeling van de vernietigbaarheid van rechtshandelingen exclusief is ten opzichte van art. 6:212, althans in die zin dat na verjaring of verval van de vernietigingsbevoegdheid de benadeelde geen vergoeding kan vorderen op grond van ongerechtvaardigde verrijking. Zie nog hiervoor nr. 28.

I027 Asser-Hartkamp/Sieburgh 6-IV, nr. 465.

I028 HR 23 september 2005, NJ 2006, I00.

I029 '3.3.2 (...) Indien moet worden aangenomen dat volgens de bedoeling van partijen de kunstvoorwerpen niet in de koop waren begrepen, doch voorwerp waren van de gelijktijdig gesloten huurovereenkomst, werd de met de door eigendomsoverdracht van die zaken bewerkstelligde verrijking immers niet door de koopovereenkomst gerechtvaardigd.'

I030 HR 9 juli 20I0, NJ 20I0, 498. 
leiden dat deze schadevergoeding alsnog aan AVA voorbij zou gaan, hebben partijen voor dat geval een voorziening getroffen in de huurovereenkomst. Vervolgens wordt de huurovereenkomst echter ontbonden wegens wanprestatie van verhuurder AVA zelf, een scenario waaraan partijen niet van te voren gedacht hadden. Het gevolg van ontbinding is dan dat ProAv feitelijk bevrijd is van haar schadevergoedingsverplichting. Daarop vordert verhuurder AVA veroordeling van huurder Proav tot betaling van $f$ I.500.00o, vermeerderd met de wettelijke rente als schadevergoeding op grond van ongerechtvaardigde verrijking in verband met het als gevolg van de ontbinding van de huurovereenkomst voor huurder Proav wegvallen van haar verplichting om aan verhuurder AVA de in de maandelijkse huursom begrepen compensatie voor het bij hun eerste gezamenlijke avontuur geleden verlies te verstrekken. Met goedvinden van de Hoge Raad past het hof hier art. 6:212 toe. ${ }^{\mathrm{IO}{ }^{\mathrm{I}}}$ Het komt er dus op neer dat een vordering uit ongerechtvaardigde verrijking eventueel wel mogelijk is wanneer een verrijking is opgetreden die niet door partijen was beoogd.

53. De Groene Specht Natuurlijk heeft het voorgaande betrekking op een overeenkomst tussen de verarmde en de verrijkte: in die verhouding heeft de overeenkomst een bijzondere betekenis. Enkel niet door de overeenkomst beoogde verschuivingen kunnen worden aangepakt. Hoe zit dat echter met een verrijking die berust op een overeenkomst tussen de verrijkte en een derde? Geldt ook daar, zoals onder meer Van Maanen en Nieskens-Isphording mede naar aanleiding van Setz/Brunings betoogden, ${ }^{\text {1032 }}$ dat de verrijking haar oorzaak en dus haar legitimatie vindt in de overeenkomst of kan de verarmde hier wel degelijk met succes tegen opkomen? ${ }^{1033}$ Hier trekt het arrest in de zaak Koker/Cornelius de aandacht. Een vrouw bewoont al bijna 20 jaar om niet een woning ('De Groene Specht') die eigendom is van haar zuster. In de loop der jaren heeft de bewoonster het huis verbeterd en er in een strijd met de gemeente voor gezorgd dat de woning bestemming 'villaklasse' heeft gekregen. Dat is de waarde zeer ten goede gekomen (alleen de grond zou al 375.000 gulden waard zijn). Nadat de eigenares eind 1997 het gebruik opzegt tegen I januari 2000, weigert de bewoonster te vertrekken en wordt een ontruimingsprocedure gestart. Inmiddels heeft de eigenares het pand voor 275.000 gulden verkocht aan haar zoon die een tweede ontruimingsprocedure start en dan met een reconventionele verrijkingsvordering wordt geconfronteerd. In deze zaak is de waarde van een woning dus vermeerderd als gevolg van investeringen door een persoon (verarmde) die daarvoor geen vergoeding heeft gekregen. Vervolgens wordt de woning door de eigenaar verkocht en geleverd aan een koper tegen een prijs die aanzienlijk lager is dan de door de investeringen verhoogde marktwaarde. De Hoge Raad maakt duidelijk dat van ongerechtvaardigde verrijking in zo'n geval in principe geen sprake is: ${ }^{\text {:034 }}$

I03I In Asser-Hartkamp/Sieburgh 6-IV, nr. 484 wordt erop gewezen dat de ontbinding, na een daartoe strekkend beroep van AVA, zou kunnen zijn afgewezen op de grond dat de betrokken tekortkoming deze ontbinding met haar specifieke gevolgen niet rechtvaardigt (art. 6:265 lid I). Dan zou het aan de orde gestelde probleem zich niet voordoen.

I032 Van Maanen 200I, p. I7-I8 en Nieskens-Isphording I998, p. I02-I03.

I033 Asser-Hartkamp/Sieburgh 6-IV, nr. 465 en 462.

I034 HR 30 september 2005, NJ 2007, I54 (JBMV) (Koker/Cornelius). Zie ook Schrage 2009, nr. I56. 
'3.6.3 (...) In een dergelijke situatie geniet de koper van de zaak, als elke koper die een zaak verwerft voor een koopprijs die beneden de marktwaarde ligt, een voordeel. Dat voordeel vindt in beginsel rechtvaardiging in de koopovereenkomst. De omstandigheid dat een derde (de verarmde) in het verleden op eigen kosten de zaak heeft verbeterd en daardoor in waarde heeft doen toenemen, brengt in het algemeen niet mee dat een zodanig verband bestaat tussen de verrijking van de koper en de verarming van de verarmde dat de koper ongerechtvaardigd verrijkt is ten koste van de verarmde.'

Voor een beroep op art. 6:212 is in een dergelijk geval dus meer nodig:

'Bij de beantwoording van de vraag of in een concreet geval de verarmde niettemin wegens bijzondere omstandigheden, in afwijking van dit uitgangspunt, jegens de koper aanspraak kan doen gelden op enige vergoeding als in art. 6:2I2 BW bedoeld, moet onder meer het volgende in aanmerking worden genomen:

a. Indien de rechtsverhouding tussen de verarmde en de verkoper meebrengt dat de verarmde de door hem gemaakte kosten zelf zou moeten dragen en de verarmde daarom géén vordering wegens ongerechtvaardigde verrijking zou hebben jegens de verkoper, zal de verarmde ook jegens de koper geen aanspraken op de voet van art. 6:212 BW geldend kunnen maken.

b. Indien de verarmde geen huurder was, verkeert hij niet in dezelfde situatie als een huurder, en is art. 7:216 BW niet van toepassing. Waar de huurder slechts indien bijzondere omstandigheden daartoe aanleiding geven jegens de verhuurder aanspraak kan maken op een vergoeding op de voet van de artikelen 7:216 lid 3 en 6:2I2 BW (HR 25 juni 2004, nr. C03/080, NJ 2005, 338, RvdW 2004, 89), is er geen reden de verarmde niet-huurder een ruimere mogelijkheid te bieden om op de voet van art. 6:2I2 BW vergoeding te eisen, te minder om hem de mogelijkheid te bieden om op de voet van die bepaling vergoeding van de koper te eisen.

c. Indien de verkoper en de koper in een familieverhouding tot elkaar staan en de verkoper een koopprijs bedongen heeft die beneden de marktwaarde ligt teneinde de koper te bevoordelen op een wijze zoals niet ongebruikelijk is bij handelingen tussen familieleden, worden die koopprijs en het door de koper genoten voordeel mede gerechtvaardigd door die bevoordelingsbedoeling. In zo'n geval is er in beginsel geen grond voor het oordeel dat de koper ongerechtvaardigd verrijkt is ten koste van de verarmde.

d. Indien al wordt geoordeeld dat de koper ongerechtvaardigd is verrijkt ten opzichte van de verarmde, zal slechts aanspraak op schadevergoeding bestaan voorzover dit redelijk is (art. 6:2I2 lid I BW). Bij de beantwoording van de vraag wat redelijk is komt betekenis toe aan de mate waarin de koper door zijn verrijking daadwerkelijk is gebaat. Voorzover de koper door de investeringen van de verarmde weliswaar verrijkt maar niet daadwerkelijk gebaat is omdat hij de gekochte woning afbreekt en ter plaatse vervangt door een nieuwe woning, is het niet zonder meer redelijk dat hij de schade zou moeten vergoeden.'

Opvallend is dat de Hoge Raad hier suggereert bijzondere omstandigheden aan te duiden die een uitzondering op de regel inhouden, terwijl enkele van de gezichtspunten 
juist weer pleiten voor de hoofdregel. ${ }^{1035}$ De betekenis van het arrest is in de eerste plaats hierin gelegen dat het belang van een overeenkomst in een geval van indirecte verrijking is benadrukt. In de tweede plaats lijkt de Hoge Raad met deze beslissing afstand te nemen van het arrest Setz/Brunings. Zowel Van Maanen ${ }^{1036}$ als Janssen ${ }^{1037}$ menen, tot hun vreugde, dat Setz/Brunings nu is achterhaald. ${ }^{1038}$ Ook wanneer een zaak wordt gekocht en geleverd aan een derde tegen een prijs die aanzienlijk lager was dan de marktwaarde, is het oordeel immers dat het voordeel in beginsel rechtvaardiging vindt in de koopovereenkomst. Het arrest geeft Van Maanen aanleiding zijn gelijk te halen: ${ }^{1039}$

'Het hek staat nu weer stevig op de dam van de actie uit ongerechtvaardigde verrijking: het is geen billijkheidsactie maar een sluitstuk van ons privaatrechtelijk systeem.'

Ook Janssen ziet dit arrest als een baken, in ieder geval voor de gevallen van indirecte verrijking. Zijn conclusie is dat de Hoge Raad nu een onmiskenbaar restrictieve koers vaart bij indirecte verrijking en daarmee afstand neemt van de stroming aangevoerd door Vranken en Hartkamp die betogen dat er geen reden bestaat voor terughoudendheid bij de toepassing van art. 6:212. ${ }^{\text {I040 }}$ Onmiskenbaar lijkt mij dat de Hoge Raad inderdaad als hoofdregel aanneemt, ook bij indirecte verrijking, dat een op een overeenkomst terug te voeren verrijking in principe gelegitimeerd is door dat contract. Slechts bij uitzondering is dat anders. ${ }^{\text {I04I }}$ Janssen en Van Maanen zitten overigens niet geheel op één lijn. Waar Van Maanen stelt dat de Hoge Raad de oplossing zoekt bij de legitimatie en daarmee bij de vraag naar de ongerechtvaardigdheid van de verrijking, betrekt Janssen de stelling dat de Hoge Raad het speelt over de band van het ontbreken van causaal verband tussen verrijking en verarming. ${ }^{1042}$ Wat daarvan zij - de overwegingen in Koker/Cornelius geven, zo lijkt het, steun aan beider opvattingen - het resultaat blijft hetzelfde. In veel gevallen van indirecte verrijking zal een verrijkingsactie niet snel (meer) slagen. Deze 'nieuwe doctrine' is voor Janssen echter aanleiding het toepassingsbereik van art. 6:212 toch weer ter discussie te stellen.

54. Op weg naar beperking van het toepassingsbereik? Mede geïnspireerd door de nieuwe koers van de Hoge Raad in Koker/Cornelius stelt Janssen voor art. 6:2I2

\footnotetext{
I035 Zo reeds Van Maanen 2006, p. 27 en Janssen 2009, p. I6r e.v. I036 Van Maanen 2006, p. 28-29.

I037 Janssen 2009, p. I64.

I038 Anders Vranken in zijn noot onder I4 e.v.

I039 Van Maanen 2006, p. 30.

I040 Janssen 2009, p. I60.

IO4I Dat blijkt ook in HR 28 oktober 20II, NJ 20I2, 495 (F.M.J. Verstijlen) (Van Hees q.q./CohenVisser):

'Het bestaan van een aan de verrijking ten grondslag liggende (rechtsgeldige) overeenkomst tussen de verrijkte en de verarmde rechtvaardigt in beginsel die verrijking, maar een verrijking van een partij bij een overeenkomst ten koste van een derde wordt niet steeds en zonder meer gerechtvaardigd door die overeenkomst, hetgeen te meer geldt bij wanverhouding tussen overeengekomen prestaties.'

I042 Janssen 2009, p. I6I.
} 
niet langer toe te passen in gevallen van indirecte verrijking, of die nu van het type Setz/Brunings en Koker/Cornelius zijn, of juist van het type Vermobo/Van Rijswijk. In het eerste type gevallen heeft de verrijkte met een ander dan de verarmde een overeenkomst gesloten die de grondslag vormt voor zijn verrijking ten koste van de verarmde die zelf geen partij is bij deze overeenkomst. In het tweede type gevallen gaat het om het spiegelbeeld. Het is de verarmde die met een ander dan de verrijkte een overeenkomst heeft gesloten die zijn verarming mogelijk heeft gemaakt, zij het niet heeft veroorzaakt: de verrijking is vaak het gevolg van de wanprestatie van de wederpartij van de verarmde. Beide typen gevallen zou Janssen dus in het vervolg buiten bereik van art. 6:2I2 willen houden. Hij kiest daarbij voor de weg van het causaal verband: in gevallen van indirecte verrijking ontbreekt het causale verband tussen verrijking bij de een en verarming bij de ander. Dat heeft alles te maken met de bezwaren die hij constateert bij indirecte verrijking: ${ }^{1043}$

- een contractspartij oriënteert zich voor haar aanspraak op nakoming of voor verhaal uitsluitend op haar wederpartij en haar vermogen; een verrijkingsactie jegens een derde is niet alleen een onverwachte meevaller maar heeft het effect van een garantie; ${ }^{1044}$

- de verarming is vaak niet het gevolg van de overeenkomst maar juist van wanprestatie van de contractsdebiteur; het is dan ongerijmd dat wanprestatie het ontstaan van een vordering op een derde (de verrijkte) tot gevolg heeft. Het civiele recht ontaardt dan in een afwentelingsmechanisme waarbij de verarmde de lasten ook nog daar kan leggen waar de kans op verhaal het grootst is;

- de vordering uit indirecte verrijking kan leiden tot een verhaalscaroussel;

- bij toepassing van art. 6:2I2 op indirecte verrijking ontbreekt een deugdelijk referentiekader met betrekking tot het causaal verband;

- vermogensrechtelijk bestaat er geen goed antwoord op de vaststelling dat de rechtsvordering tegen de derde/verrijkte de nakomingsactie tegen zijn contractdebiteur niet uitschakelt; hierdoor dreigt een ongerechtvaardigde verrijking van de verarmde en gaat de rechtsvordering in haar tegendeel verkeren. Om dat te

I043 Janssen 2009, p. I58 e.v.

I044 Zie ook Hartkamp 200I, p. 3i6 die ingaat op het bezwaar van het erkennen van een verrijkingsactie bij indirecte verrijking, namelijk dat zij ertoe leidt dat een crediteur het faillissement van wederpartij kan omzeilen door zich op verrijkte te verhalen en daardoor tot ongerechtvaardigd voordeel ten opzichte van zijn medecrediteuren. Hartkamp relativeert dit eerst: dit heeft hoogstens betekenis indien de verrijkte ten koste van zijn medecrediteuren is bevoordeeld, zoals wanneer verhaal op de verrijkte leidt tot onttrekking van vermogensbestanddeel aan de boedel van zijn wederpartij (nl. een vordering van haar boedel op de verrijkte). Dat hoeft echter niet het geval te zijn, in welk geval de verhaalspositie van andere crediteuren juist wordt verbeterd (immers de vordering van de verarmde is dan al voldaan). Verder wijst hij erop dat het elke crediteur vrijstaat zich door het bedingen van zekerheden een zo gunstig mogelijke positie te verschaffen. Liever dan een belangrijke groep zonder meer van een verrijkingsactie uit te sluiten zou Hartkamp de gewenste beslissing in de concrete zaak willen laten afhangen van een afweging van de in zaak aan de orde zijnde belangen. 
voorkomen moeten we ons bedienen van een paardenmiddel als de beperkende werking van de redelijkheid en billijkheid. ${ }^{\text {I045 }}$

Hoewel de Hoge Raad zijn opvattingen niet heeft overgenomen, althans uit zijn rechtspraak valt af te leiden dat hij nog altijd voor zich ziet dat art. 6:2I2 op gevallen van indirecte verrijking wordt toegepast, ${ }^{1046}$ maken de bezwaren van Janssen wel indruk. Noch wetgever noch rechtspraak is tot nu toe gediend van categorische abstracte benaderingen. Dat heeft als consequentie dat met genoemde bezwaren voor zover mogelijk rekening dient te worden gehouden bij de toepassing van concrete gevallen. ${ }^{\text {1047,1048 }}$

55. Groeimogelijkheden Een geheel andere invalshoek kiezen enkele andere auteurs. Zij zijn niet op zoek naar beperking van het toepassingsbereik doch juist naar de 'groeimogelijkheden' van de verrijkingsactie. In dit verband stellen zij de vraag of het verarmingsvereiste, het schadevereiste, wel handhaving verdient. Ongeveer tezelfder tijd hebben Linssen ${ }^{1049}$ en Van Boom ${ }^{1050}$ zich deze vraag gesteld. Het vereiste leidt ertoe dat in bepaalde gevallen de verrijkte (een deel van) zijn voordeel mag behouden, omdat er geen schade is of omdat de schade kleiner is dan de verrijking. Zou het daarom geen aanbeveling verdienen een 'echte' verplichting tot verrijkingsafdracht te introduceren ${ }^{\text {Io5 }}$ Linssen brengt het verrijkingsinstrument hier in verband met de bescherming die de rechthebbende op een goed toekomt. Bij hem heeft de verrijkingsafdracht dan een vergelijkbare functie als de revindicatie: waar de revindicatie ertoe strekt het object van eigendom als zodanig terug te krijgen, gaat het bij de verrijkingsvordering om het 'terugvorderen' van ten onrechte met het goed genoten voordelen. ${ }^{1052} \mathrm{Hij}$ stelt het schadevereiste niet; voor de revindicatie is schade immers ook geen voorwaarde. Van Boom beperkt zijn beschouwingen niet tot goederenbescherming ${ }^{1053}$ en pleit voor een ruimere verrijkingsafdracht niet alleen op basis van art. 6:212 maar ook op basis van art. 6:162. Hij denkt daarbij

I045 Het gaat hier in wezen om het op ongerechtvaardigde verrijking gebaseerde verweermiddel dat hiervoor in nr. 45 aan de orde kwam.

I046 Zie bijv. HR 28 oktober 20II, NJ 20I2, 495 (F.M.J. Verstijlen) (Van Hees q.q./Cohen-Visser).

I047 Zie in dit verband ook hiervoor in nr. 47.

I048 Vriesendorp 20I2, nr. 3I3 geeft aan handhaving van deze lijn ook de voorkeur en stelt dat eventuele uitwassen beter dan met het ontkennen van een causaal verband kunnen worden bestreden met het ontkennen van het ontbreken van een legitimatie voor de vermogensverschuiving: de verrijking is dan dus niet ongerechtvaardigd. Zie ook Hartkamp 200I, p. 3 I6.

I049 J.G.A. Linssen, Voordeelsafgifte en ongerechtvaardigde verrijking. Een rechtsvergelijkende beschouwing, diss., Boom Juridische uitgevers, Den Haag 200I. Zie ook Linssen 2002, p. 67 waar wordt gesteld dat we nog altijd geen volwaardig verrijkingsrecht hebben. Hij pleit er daarom voor de schade-eis te schrappen.

I050 W.H. van Boom, Verrijkingsafdracht en aansprakelijkheid, preadvies VBR, Kluwer, Deventer 2002, p. 7 I e.v. Overigens denkt T.E. Deurvorst, Schadevergoeding, redelijke gebruiksvergoeding en winstafdracht bij inbreuk op intellectuele eigendomsrechten, diss. Utrecht, Kluwer, Deventer 1994 in dezelfde richting.

I05I Zie ook Schrage 2009, nr. I23 e.v.

I052 Zie ook Linssen 2002.

I053 Van Boom 2002, p. 97: het verrijkingsrecht en het aansprakelijkheidsrecht gaan over meer dan alleen bescherming van exclusieve vermogensposities. 
onder meer aan opzettelijke onrechtmatige gedragingen ${ }^{1054}$ en aan andere gevallen waarin het huidige aansprakelijkheids- en schadevergoedingsrecht bijvoorbeeld als 'prikkelend mechanisme' faalt: ${ }^{\text {:o5s }}$ het gebruik van een verhaallijn in een film, nadat onderhandelingen over verfilming juist waren afgeketst, belediging van een publieke persoon in de boulevardpers, strooischade (waarbij zeer velen slechts met beperkte schade worden geconfronteerd). Interessant is zijn beschouwing over de verschillen en overeenkomsten tussen het aansprakelijkheidsrecht en het verrijkingsrecht. Waar het eerste zich concentreert op onjuist gedrag, gaat het in het verrijkingsrecht om de vraag of de verrijking door het systeem wordt gelegitimeerd of niet. Bij nadere beschouwing, zeker van de rechtspraak van de Hoge Raad, blijkt echter, aldus Van Boom, dat het ook bij art. 6:2I2 veelal neerkomt op een toetsing van het gedrag van de verrijkte. ${ }^{1056}$ Enigszins in lijn met de unclean hands-gedachte van Vranken ${ }^{1057}$ lijkt Van Boom voor toepassing van de verrijkingsactie van belang te achten dat de verrijkte een verwijt kan worden gemaakt van het niet voorkomen van de verrijking. ${ }^{1058} \mathrm{Hij}$ maakt daarvan gebruik om het verrijkingsrecht naast het aansprakelijkheidsrecht in te zetten, namelijk daar waar dat tegen zijn grenzen aanloopt, ${ }^{1059}$ ter beïnvloeding van gedrag (prikkelwerking) en om een efficiënte allocatie van kosten van maatschappelijke activiteiten te realiseren. Het verrijkingsrecht zou er bijvoorbeeld aan kunnen bijdragen dat bepaalde schadelijke activiteiten een juiste prijs krijgen. ${ }^{\text {1060 }}$

56. Surrogaat-oplossingen Zowel in het aansprakelijkheidsrecht als in het verrijkingsrecht stuit men echter op dit moment op de schade-eis. Weliswaar kent het Nederlands recht met art. 6:I04 een bepaling die wel in verband met verrijkingsafdracht wordt gebracht, maar in de geldende uitleg ervan heeft zij weinig betekenis. Art. 6:I04 luidt als volgt:

'Indien iemand die op grond van een onrechtmatige daad of tekortkoming in de nakoming van een verbintenis jegens een ander aansprakelijk is, door die daad of tekortkoming winst heeft genoten, kan de rechter op vordering van die ander de schade begroten op het bedrag van die winst of op een gedeelte daarvan.'

Deze bepaling die beperkt is tot aansprakelijkheid op grond van onrechtmatige daad of wanprestatie ${ }^{\mathrm{I0} 6 \mathrm{I}}$ biedt echter, althans in de uitleg van de Hoge Raad, ${ }^{\text {1062 }}$

I054 Van Boom 2002, p. I05 e.v.

I055 Van Boom 2002, p. I09.

I056 Van Boom 2002, p. II3 e.v.

I057 Hiervoor nr. 43 .

I058 Van Boom 2002, p. I22.

I059 Van Boom 2002, p. I22 e.v.

Io6o Van Boom 2002, p. I32-I35 waar hij het voorbeeld van roken behandelt.

I06I Uitbreiding naar art. 6:2I2 is uitdrukkelijk afgewezen bij de totstandkoming van art. 6:104. Zie MvA II Inv., Parl.Gesch. Boek 6 (Inv.), p. I267 en Nota II Inv., Parl.Gesch. Boek 6 (Inv.), p. I268-I269. Daar wordt gehecht aan handhaving van het verarmingsvereiste bij art. 6:2I2.

I062 HR 24 december I993, NJ I995, 42I (CJHB) (Waeijen-Scheers/Naus) en HR I8 juni 20I0, RudW 20I0, 77I (Doerga/Stichting Ymere) en 772 (Setel/AVR Holding). 
geen zelfstandig recht op winstafdracht, doch is slechts een begrotingsregel: zij geeft de rechter in gevallen waarin schade aannemelijk is maar bijvoorbeeld lastiger te bewijzen dan het voordeel dat de laedens heeft genoten, de bevoegdheid om deze te begroten op (een gedeelte van) de winst die de laedens heeft geboekt. Naar de huidige stand van het recht kan men hier weliswaar wat aan doen door snel 'enige schade' aannemelijk te achten of door van een abstract schadebegrip uit te gaan, ${ }^{106}{ }_{3}$ maar daarmee realiseert men niet de wezenlijke uitbreiding, die Linssen en Van Boom kennelijk voorstaan.

57. Waardering Het is goed om de vraag te stellen of een rechtsgebied zijn doelstellingen weet te realiseren en in dat verband kan, mocht het antwoord ontkennend luiden, het aangewezen zijn om tot aanpassingen te komen. Waar het bijvoorbeeld om de doelstellingen van het aansprakelijkheidsrecht gaat (rechtshandhaving, preventie, kostenallocatie) ben ik best bereid om stappen te zetten bijvoorbeeld op het punt van de sancties om voldoende prikkelwerking te genereren. Daarbij kan worden gedacht aan een hoger smartengeld, ${ }^{1064}$ aan een zelfstandige vordering tot winstafdracht en eventueel zelfs aan punitive damages. ${ }^{1065}$ In dit verband kan een minder terughoudende uitleg van art. 6:I04 waarschijnlijk al veel kou uit de lucht nemen. ${ }^{\text {1066 }}$ Wat Van Boom voorstelt, gaat echter verder. Hij zet zijn geld behalve op aanpassingen binnen het aansprakelijkheidsrecht ook op het verrijkingsrecht als zodanig ter realisering van vergelijkbare doeleinden als het aansprakelijkheidsrecht. Dat geeft een hele andere plaats aan het verrijkingsrecht dan tot nog toe het geval is: van een, nuttige, bijrol in het kader van aanvulling en verfijning, ${ }^{1067}$ krijgt het bij hem een hoofdrol: het komt als vergelijkbaar coherent systeem naast het aansprakelijkheidsrecht te staan. Er is al door anderen gewezen op de verschillen in perspectief van het aansprakelijkheids- en verrijkingsrecht. ${ }^{1068}$ Waar het eerste het gedrag tot uitgangspunt neemt en daarop een aansprakelijkheid baseert, gaat het in het verrijkingsrecht

I063 Van Boom 2002, p. I45, Schrage 2009, nr. I25, Vriesendorp 20I2, nr. 3I2 en Snijders 200I, nr. II. Zie overigens ook nog, in de context van (het aanpakken van) corruptie E.H.J. Schrage, 'Steekpenningen voor het forum van het privaatrecht', NTBR 20II, p. 44 e.v.

Io64 De mogelijkheden daartoe worden niet steeds benut. Zie bijvoorbeeld Rb. Amsterdam 2 februari 2005, Intellectuele Eigendom en Reclamerecht 2005, 44 (E.H. Hoogenraad) waarin toenmalig premier Balkenende zich beklaagt over het gebruik van een cartoon waarop hij als kleuter wordt afgebeeld in moederdagreclame-uitingen van Kijkshop ('zonder verkoper shopt J-Peetje goedkoper'). Smartengeld (en overigens ook toepassing van art. 6:I04) werd afgewezen. Met toewijzing van een verklaring voor recht zou Balkenende reeds voldoende schadeloos zijn gesteld.

Io65 Zie T. Hartlief, Anno 2010. Beschouwingen over Aansprakelijkheid en Verzekering, DeLex, Amsterdam 2009, p. 66 e.v. en L. Meurkens en E. Nordin (red.), The Power of Punitive Damages, Intersentia, Cambridge/Antwerpen/Portland 2012.

Io66 J. Kortmann en C. Sieburgh, 'Handhaving door het Nederlands privaatrecht', in: Rechtshandhaving door privaatrecht, preadvies voor de Vereniging voor de vergelijkende studie van het recht van België en Nederland, Boom Juridische uitgevers, Den Haag 2009, p. 288-289 en 300 geven juist bij de handhaving van persoonlijkheidsrechten wel de voorkeur aan een op de verrijkingsgedachte gebaseerde voordeelsafdracht, zij het dat zij daarbij beperkingen aanbrengen. In ieder geval prefereren ze dit boven oplossingen binnen het schadevergoedingsrecht, omdat zij daar zouden botsen op de primair compensatoire functie van het schadevergoedingsrecht.

Io67 Hiervoor nr. I4 en 49.

Io68 G.E. van Maanen, 'Ongerechtvaardigde verrijking! Bespreking preadviezen Van Boom en Wissink voor de Vereniging voor Burgerlijk Recht,' NTBR 2002, p. I80. 
om iets geheel anders: daar kijkt men naar een bepaald resultaat en stelt men zich de vraag of een bepaalde verschuiving door het systeem gerechtvaardigd is. Anders dan Van Boom probeert ingang te doen vinden, staat daarbij het gedrag van de verrijkte niet centraal althans is een eventuele gehoudenheid tot vergoeding niet gebaseerd op diens onbetamelijk gedrag. Zou dat veranderen, dan zou de verhouding tussen verrijkingsrecht en aansprakelijkheidsrecht steeds lastiger worden, omdat dan in veel gevallen twee vergelijkbare grondslagen in beeld komen. Het is de vraag wat we daarmee zouden bereiken. Ik zie daarmee in ieder geval nog geen winst geboekt.

\section{Eindbalans}

58. Tot besluit Voor de Nederlandse situatie is van groot belang dat er sinds 1992 een algemene verrijkingsactie in het $\mathrm{BW}$ is opgenomen waar voor verrijkingsacties onder het oude recht op het eerste gezicht slechts zeer beperkt plaats was. Bovendien blijkt uit de parlementaire historie dat het hier gaat om een leerstuk in ontwikkeling: de toelichtende stukken zetten veel geld op rechtspraak en doctrine. De Hoge Raad heeft daarbij na 1992 inderdaad de leiding genomen en veel ruimte gegeven aan toepassing van art. 6:2I2. Zijn rechtspraak heeft de nodige, soms forse, kritiek in de doctrine uitgelokt. Een en ander heeft in ieder geval geleid tot een uitvoerig debat over plaats en functie(s) van de verrijkingsactie. Bovendien lijkt de rechtspraak, wellicht in reactie op de literatuur, op haar schreden teruggekeerd. Art. 6:2I2 lijkt inmiddels minder ruimhartig dan voorheen te worden toegepast. Laat ik tot besluit de belangrijkste bevindingen op een rijtje zetten:

I. Het huidige Nederlandse recht kent in art. 6:212 een algemene verrijkingsactie die niet op voorhand aan banden is gelegd. Het beeld is dat de verrijkingsactie veel ruimte heeft. Er geldt immers geen subsidiariteitsvereiste. Volgens de normale samenloopregels kan bovendien al snel een actie uit ongerechtvaardigde verrijking worden ingesteld hoewel ook andere grondslagen beschikbaar zijn. En dat een afwijzend antwoord ('nul op het rekest') in het kader van een andere grondslag zonder meer betekent dat de verrijkingsactie ook moet worden afgewezen, kan niet in zijn algemeenheid worden gezegd. Natuurlijk kan ter relativering worden gezegd dat in heel veel gevallen andere grondslagen voor vergoeding of bronnen van verbintenissen kunnen en dan ook zullen worden benut. Grote behoefte aan art. 6:2I2 is er dan niet. In eerste instantie is de vraag of de verrijkingsvordering kan worden ingesteld vooral van belang indien de verrijkte niet reeds op basis van een andere grondslag kan worden aangesproken, bijvoorbeeld omdat aan de voorwaarden voor die andere grondslag niet is voldaan. Daarbij valt te denken aan het geval dat een derde een schuld betaalt zonder 'redelijke grond' of in de veronderstelling dat hij zijn eigen schuld voldoet. In dat geval kan art. 6:198 (zaakwaarneming) geen uitkomst bieden omdat aan de daarin gestelde voorwaarden niet is voldaan. Een tweede categorie van gevallen betreft die waarin andere grondslagen niet tot vergoeding van de (gehele) schade van de benadeelde strekken. Te denken valt hier aan het geval dat iemand 
onverschuldigd een zaak levert, deze weliswaar kan terugvorderen op basis van art. 6:203 maar op die grondslag geen vergoeding kan krijgen voor het gebruik dat de ander enige tijd van de zaak heeft gehad. Een dergelijke vergoeding zou wel op art. 6:2I2 kunnen worden gebaseerd. Een derde categorie is meteen problematisch: er is juist wel een andere, veelal contractuele, grondslag in beeld, maar omdat de debiteur een insolventieprobleem heeft, gaat de crediteur op zoek naar een andere wel solvabele debiteur die hij op basis van art. 6:2I2 aanspreekt.

2. Hoewel art. 6:212 een volwaardige bron van verbintenissen is, is het ook een bijzondere bron, omdat toepassing van art. 6:212 per definitie inhoudt dat onder de noemer van de vraag of de eventuele verrijking ongerechtvaardigd is het wettelijk systeem moet worden afgetast en moet worden doorgrond. Dat is weliswaar niet hetzelfde als zeggen dat de bepaling restrictief moet worden toegepast, zij moet immers serieus worden genomen en in haar rol 'vol' worden benut, maar uit de aard der zaak volgt dat het systeem moet worden beoordeeld. Dat maakt deze actie dus anders dan andere. Zij vult het systeem aan, geeft mogelijkheden tot verdere ontwikkeling en verfijning en completeert het dus. Dat is positiever geformuleerd dan de beelden die anderen wel gebruiken ('sluitstuk', 'noodventiel'), maar het is de vraag of dezen in concrete gevallen werkelijk tot andere resultaten zouden komen.

3. Wel juist lijkt mij de bewering dat het verrijkingsrecht als zodanig, juist vanwege zijn aanvullende en completerende rol geen coherent geheel van regels oplevert. ${ }^{1069}$ Weliswaar hebben Linssen en Van Boom zich sterk gemaakt voor een zelfstandig verrijkingsrecht waarin in plaats van vergoeding van de schade veeleer afdracht van het door de verrijkte genoten voordeel centraal staat, mij hebben ze nog niet overtuigd. Ik ben geen voorstander van het laten vallen van het verarmingsvereiste en evenmin van het optuigen van een verrijkingsrecht dat zich in aanvulling op en ter versterking van het aansprakelijkheidsrecht zou bezighouden met functies die in wezen thuishoren in het aansprakelijkheidsrecht. Het lijkt dan beter de oplossing - liefst binnen dat systeem - te zoeken in verbetering van het sanctiearsenaal waarbij onder meer te denken valt aan een aanscherping van art. 6:I04 of (vormen van) abstracte schadebegroting. Vooralsnog geef ik dus de voorkeur aan differentiatie binnen het aansprakelijkheidsrecht waar eventueel verruimde mogelijkheden tot winst- of voordeelsafdracht kunnen worden geïntroduceerd wanneer dat in het kader van rechtshandhaving, afschrikking of preventie aangewezen is. Dat dergelijke figuren buiten de sfeer van het aansprakelijkheidsrecht ook wenselijk zijn, is mij nog niet overtuigend gebleken. Niet toevallig komt Van Boom bij de uitwerking van zijn opvattingen uit bij een systeem dat niet alleen wat doelstellingen, maar ook wat voorwaarden

Io69 Zie in dit verband J.M. Smits, 'Een Europees recht inzake ongerechtvaardigde verrijking? Over de dogmatiek van het Ontwerp-Gemeenschappelijk Referentiekader', Groninger Opmerkingen en Mededelingen 2008, p. 97 e.v. 
betreft, dicht tegen het aansprakelijkheidsrecht aan zit. Beter dan een cumulatie van systemen lijkt het uitbreiden van het sanctiearsenaal binnen het aansprakelijkheidsrecht. Differentiatie en aanpassing dus in plaats van stapeling van systemen.

4. Het potentieel zeer ruime toepassingsbereik maakt de algemene verrijkingsactie van art. 6:212 tot een omstreden rechtsfiguur. Niet alleen wordt de vordering onbepaald en ongrijpbaar genoemd, men vreest pure billijkheidsrechtspraak en ook doorkruising van hetgeen in het kader van andere rechtsfiguren en leerstukken is ontwikkeld. De Nederlandse discussie is op scherp gezet door de rechtspraak van de Hoge Raad in de eerste jaren na inwerkingtreding van het BW 1992. De rode draad in de kritiek is dat de Hoge Raad te veel ruimte geeft aan art. 6:2I2 en te weinig oog heeft voor andere vorderingen die binnen het systeem al bestaan. Rond de eeuwwisseling heeft dit geleid tot een stevig debat over plaats en functies van art. 6:2I2. Dat heeft een zekere duidelijkheid gegeven: zo worden in ieder geval aanvulling, beperking en zingeving tamelijk algemeen als functie onderkend.

5. De beperkende functie of werking hangt sterk samen met de ruimte die er is voor gevallen van indirecte verrijking. Omdat die naar huidig recht niet stelselmatig van toepassing van art. 6:212 zijn uitgesloten, ontstaat er behoefte aan een verweermiddel dat bijvoorbeeld 'dubbel profiteren' moet voorkomen. En ook in 'Europese' en in de mededingingsrechtelijke ${ }^{\text {I070 }}$ context blijkt de behoefte aan een op ongerechtvaardigde verrijking gebaseerd verweermiddel bijvoorbeeld tegen vorderingen op basis van onverschuldigde betaling of onrechtmatige daad. ${ }^{1071}$

6. Na een hausse aan aandacht in de periode I998-2002 lijkt er een zekere rust aan het front gekomen. Dat heeft wellicht ook hiermee te maken dat de Hoge Raad na 2002 enkele arresten heeft gewezen waarin hij zich bepaalde kritiek lijkt te hebben aangetrokken. Deze kennen overwegingen die uitvoeriger en inzichtelijker zijn dan in arresten voordien. Belangrijk is vooral dat de Hoge Raad op het punt van de vraag of de verrijking is gerechtvaardigd door een in het geval betrokken

I070 Een heel ander geval is aan de orde in Hof Arnhem ro januari 20I2, Jurisprudentie Aansprakelijkheid 20I2, 6I: de Staat claimt ex art. 6:173 (aansprakelijkheid van de bezitter voor schade veroorzaakt door een gebrekkige roerende zaak) vergoeding van de schade aan het wegdek als gevolg van het feit dat een auto is uitgebrand. (De WAM-verzekaar van) de eigenaar verweert zich: toewijzing leidt tot ongerechtvaardigde verrijking van de Staat die immers ook al belasting heeft ontvangen. Het verweer slaagt overigens in casu niet.

I07I Zie bijvoorbeeld Asser-Hartkamp 3-I, nr. 87-88, I2I, I37 en Hartkamp 20II, p. 332 e.v. waar het gaat om gevallen waarin toewijzing van een actie uit onverschuldigde betaling of schadevergoeding zou leiden tot een verrijking omdat de crediteur de lasten al heeft doorberekend aan zijn afnemers (doorberekenings- of passing on-verweer). Bij schadevergoedingsacties zal de vordering, ervan uitgaande dat het verweer wordt gehonoreerd, dan worden afgewezen wegens het ontbreken van schade. Zie overigens kritisch over het verweer in de context van het mededingingsrecht B.T.M. van der Wiel, 'Schadevergoeding bij schending van het mededingingsrecht', NJB 2009, p. 724 e.v. 
overeenkomst ook zijn koers lijkt te hebben aangepast. Zowel in gevallen van directe als van indirecte verrijking komt in principe, zij het niet zonder uitzonderingen, legitimerende werking toe aan een overeenkomst die aan het voordeel of de verrijking ten grondslag ligt. Het effect van deze rechtspraak is dat art. 6:2I2 in minder gevallen dan voorheen met succes kan worden ingeroepen. ${ }^{\mathrm{1072}}$

7. Hoewel herhaaldelijk, soms via een specifieke invulling van het verarmingsvereiste, soms via een specifieke benadering van het causaal verband, in de literatuur wordt getracht gevallen van indirecte verrijking buiten de deur van art. 6:2I2 te houden, lijken de pleitbezorgers weinig kans van slagen te maken. Weliswaar zijn aan toepassing van art. 6:212 in gevallen van indirecte verrijking bezwaren verbonden die serieus genomen moeten worden, doch nu wetgever noch rechtspraak gediend blijken van categorische abstracte benaderingen, moet met deze bezwaren voor zover mogelijk rekening worden gehouden bij de toepassing in concrete gevallen.

8. Het leerstuk van de ongerechtvaardigde verrijking is ongetwijfeld nog in ontwikkeling. Na enige heftige horten en stoten in rechtspraak en doctrine in de periode I992-2002 lijkt de ongerechtvaardigde verrijkingsactie op dit moment in rustiger vaarwater terecht gekomen.

9. Of het hek ooit van de dam is geweest en of het inmiddels weer terug is, beide worden beweerd door mijn proximus Van Maanen, weet ik niet. Wat ik vooralsnog meen aan te treffen, zowel in doctrine als in rechtspraak, een enkel minder geslaagd arrest daargelaten, is de wens om zuivere billijkheidsoordelen te voorkomen en in plaats daarvan juist, ook al is men bezig met aanvulling en verfijning, binnen het systeem te blijven.

Io. Dat laatste lijkt mij zowel voor het Nederlandse als het Belgische recht een nobel streven.

\section{Verkort aangehaalde literatuur}

\section{Asser-Hartkamp/Sieburgh 6-IV}

Asser-Hartkamp/Sieburgh 6-IV, Verbintenissenrecht. De verbintenis uit de wet, $13^{\mathrm{e}} \mathrm{druk}$, Kluwer, Deventer 20II.

I072 De aandacht verschuift inmiddels naar ontwikkelingen in Europees verband zoals onder meer blijkt uit Asser-Hartkamp 3-I. Zie ook Schrage 2009, p. I03 e.v. Of Boek VII van het DCFR de toon zal gaan zetten, weet ik niet. In de doctrine is de aandacht al snel afgeleid wanneer er andere, 'meer tastbare' ontwikkelingen aan de orde zijn, zoals op dit moment duidelijk het geval is met het kooprecht. Zie onder veel meer A.L.M. Keirse, S.A. Kruisinga en Y. Schaub, 'Nieuws uit Europa: Twee nieuwe wetgevingsinstrumenten: de Richtlijn Consumentenrechten en het gemeenschappelijk Europees Kooprecht', Contracteren 20I2, p. II e.v. en diverse bijdragen in Maandblad voor Vermogensrecht 2012, nummer $7 / 8$. 